\title{
Overview on the hydrodynamic conditions found in industrial systems and its impact in (bio)fouling formation
}

\author{
Susana Fernandes ${ }^{a}$, Inês B. Gomes ${ }^{\text {a }}$, Lúcia C. Simões ${ }^{b}$, Manuel Simões ${ }^{a, *}$ \\ ${ }^{a}$ LEPABE - Laboratory for Process Engineering, Environment, Biotechnology and Energy, Faculty of Engineering, University of Porto, Rua Dr. Roberto Frias, $4200-465$ \\ Porto, Portugal \\ ${ }^{\mathrm{b}}$ CEB, Centre of Biological Engineering, University of Minho, Campus de Gualtar, Braga, Portugal
}

\section{A R T I C L E I N F O}

\section{Keywords:}

Distribution network

Biofouling

Heat exchanger

Reynolds number

Shear stress

Stirrer tank

\begin{abstract}
A B S T R A C T
Biofouling is the unwanted accumulation of deposits on surfaces, composed by organic and inorganic particles and (micro)organisms. Its occurrence in industrial equipment is responsible for several drawbacks related to operation and maintenance costs, reduction of process safety and product quality, and putative outbreaks of pathogens. The understanding on the role of operating conditions in biofouling development highlights the hydrodynamic conditions as key parameter. In general, (bio)fouling occurs in a higher extension when laminar flow conditions are used. However, the characteristics and resilience of biofouling are highly dependent on the hydrodynamic conditions under which it is developed, with turbulent conditions being associated to recalcitrant biodeposits. In industrial settings like heat exchangers, fluid distribution networks and stirred tanks, hydrodynamics plays a dual function, affecting the process effectiveness while favouring biofouling formation. This review summarizes the hydrodynamics played in conventional industrial settings and provides an overview on the relevance of hydrodynamic conditions in biofouling development as well as in the effectiveness of industrial processes.
\end{abstract}

\section{Introduction}

Industrial fouling is the unwanted build-up of organic/inorganic particles and organisms on surfaces. The mechanisms involved in fouling development (i.e. crystallization, particulate deposition, chemical reactions, corrosion and biofilms) are well described by Coletti et al. [1]. In general, fouling comprises sequential and/or simultaneous stages $[1,2]$ as presented in Fig. 1: (A) Initiation by convective transport and deposition of fouling precursors (foulants), creating a conditioning layer that attracts more foulants; (B) Diffusion transport of foulants from the bulk fluid to the surface; (C) Attachment of foulants on the surface involving mass transfer, chemical reactions, and/or biological adhesion processes; (D) Removal by shear effects on the surface; (E) Fouling ageing based on a dynamic equilibrium between the overall deposition and removal forces $[1,2]$.

Several operating conditions affect fouling development such as physical and chemical properties of the fluid bulk (e.g. salt content, solid particle size, $\mathrm{pH}$, ionic strength); surface properties (e.g. hydrophobicity, roughness); temperature profile between the fluid bulk and the surface; and hydrodynamic conditions (e.g. flow velocity, shear stress on the surface, equipment geometry, fluid stagnation/dead-end zones) [3,4]. In general, the hydrodynamic conditions play the main role in fouling phenomena, resulting in two opposite effects - molecular transport and mechanical stress [5]. While high fluid velocity determines the rate of mass transport from the fluid bulk towards the surface - promoting fouling formation; high shear stress is responsible for surface erosion and sloughing - reducing fouling [2,5]. Furthermore, other operating conditions could impact fouling occurrence. For example, in dairy pasteurization, the temperature profile plays the most important effect in fouling by being a key factor in protein denaturation and consequent deposition $[4,6]$.

Industrial fouling is responsible for several technical and economic problems, such as reduction of heat and mass transfer efficiency, blockage of fluid flow, high-pressure drop, microbial accumulation, corrosion and metal fatigue [4]. In fact, the annual costs associated to all types of fouling in industrially developed countries is estimated at $0.25 \%$ of the gross domestic product (GDP) $[7,8]$. Specifically, in the food and pharmaceutical industries, biofouling is of particular concern due to the potential accumulation of unwanted and spoilage microorganisms [9]. Thus, to ensure high operating productivity and high safety

\footnotetext{
* Corresponding author.

E-mail address: mvs@fe.up.pt (M. Simões).
} 
conditions, production lines are often cleaned daily by cleaning-in-place (CIP) procedures. CIP procedures consist on cleaning the inner surface of equipment (e.g. pipes, tanks, process units) without disconnecting them [10]. Li et al. [10] reviewed CIP procedures highlighting the role of hydrodynamic conditions. High shear stress and turbulent flow of sanitisers improved fouling detachment and sanitiser transfer towards the surface, enhancing CIP efficacy [11]. On the other hand, low shear stress hindered CIP procedures, resulting in deficient and non-uniform spread of sanitiser in all the network as well as its removal [12].

In particular, biofouling results from the adhesion of both micro and macroorganisms on surfaces. Typically, the initial stage is the bacterial adhesion, followed by the colonization by microalgae, diatoms and macroorganisms, like mussels, tubeworms and algae [13]. The production of a matrix of extracellular polymeric substances (EPS) by the colonizing organisms provides protection against external chemical and mechanical stresses, and confers distinct viscoelastic and cohesive properties, according to the external hydrodynamic conditions [14]. Furthermore, the hydrodynamic conditions can influence biofouling morphology and distribution, cell density and EPS matrix composition and abundance $[13,15-19]$. These distinct biofouling properties seem to impact the behaviour (i.e. viability, tolerance and ability to recover) of the colonizing microorganisms to chemical and mechanical stresses [20-24].

The understanding of the role of hydrodynamic conditions in fouling formation on industrial settings is relevant for both industry and academia. In fact, the hydrodynamic conditions are involved in the process design and optimization, being directly related to the operating costs and product quality in several industries [25]. However, the relationship between hydrodynamics and fouling phenomena in industrial settings has not been considered as a target topic in recent reviews. Thus, the present study critically reviews the impact of hydrodynamics in (bio)fouling phenomena on industrial applications, covering publications between 2010 and 2020 (Fig. 2). Heat exchangers (HEs), distribution networks and stirred tanks are identified as the main industrial units where fluid hydrodynamics concerns both process effectiveness and (bio)fouling phenomena. Firstly, this review focus on biofouling impact in industrial settings by given specific examples of related problems. A brief description of hydrodynamic behaviour in each process unit is also provided. Finally, the role of hydrodynamic conditions in biofouling control and prevention is also discussed.

\section{2. (Bio)fouling in industrial processes}

In natural environments, microorganisms commonly appear in complex structures, called biofilms. Biofilms consist of microorganisms adhered on biotic and abiotic surfaces that are embedded in a selfproduced matrix of EPS [26]. Such a structure confers multiple

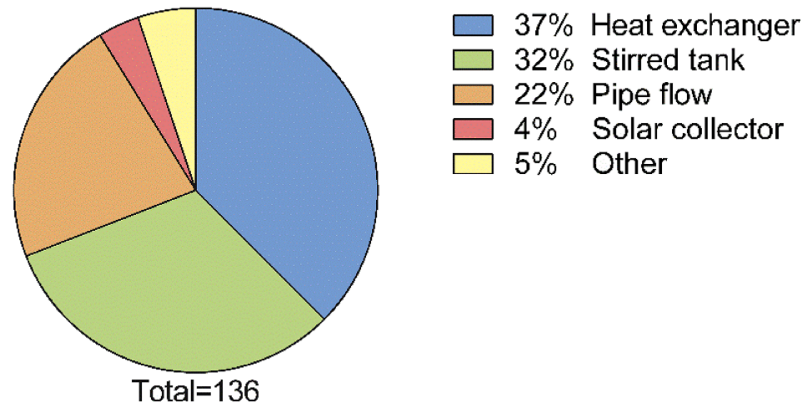

Fig. 2. Reviewed data on industrial applications related to hydrodynamic conditions. From Scopus database (TITLE-ABS-KEY (industrial AND (("flow rate" AND pipe) OR "shear stress" OR "shear rate" OR Reynolds)) AND PUB$Y E A R>2009$ ), a total of 3196 articles were retrieved, then only 136 articles followed the main research requisites (data obtained in 18th March 2020). The studies about membrane fouling were not included in the scope of this review.

advantages to cells like protection against external stresses caused by low cell accessibility, protection from antimicrobial agents due to chemical interactions with biofilm constituents, microenvironment heterogeneity and phenotype differentiation with low metabolic activity [27]. In industrial settings, under organically and inorganically enriched environments, "pure" biofilms are atypical, and microorganisms appear in a complex biodeposit associated to inorganic matter called biofouling. Thus, industrial biofouling is inevitable as a prevailing microbial lifestyle. For instance, several authors have reported bacterial persistence in meat processing surfaces after cleaning and disinfection [28,29]. Moreover, all industrial settings related to biofouling events have additional operating and maintenance costs due to an additional energy, cost of additives (i.e. sanitisers) and unplanned shutdowns for process cleaning and disinfection [30].

Industrial biofouling is mainly reported for cooling water systems (e. g. water reservoir tanks, towers, pipelines and HEs) [31]. These are mostly used to dissipate heat generated by the industrial process, using water from natural sources. The presence of biofouling promotes metal corrosion, reduction of heat transfer efficiency, increase of pressure drop, and pipe blockage [32]. Moreover, it has been associated to public health problems and waterborne outbreaks, due to the survival and proliferation of pathogens, like Legionella spp. As example, in New York city, in 2015, three Legionella spp. outbreaks occurred with 138 cases (13 deaths) [33]. One year before, in Portugal, it was registered an outbreak of legionnaires' disease that infected 377 people (confirmed cases) and caused 14 deaths [34]. In both outbreaks, cooling towers were identified as the sources of Legionella species. This kind of cooling systems provided the ideal conditions for its growth and persistence, and final

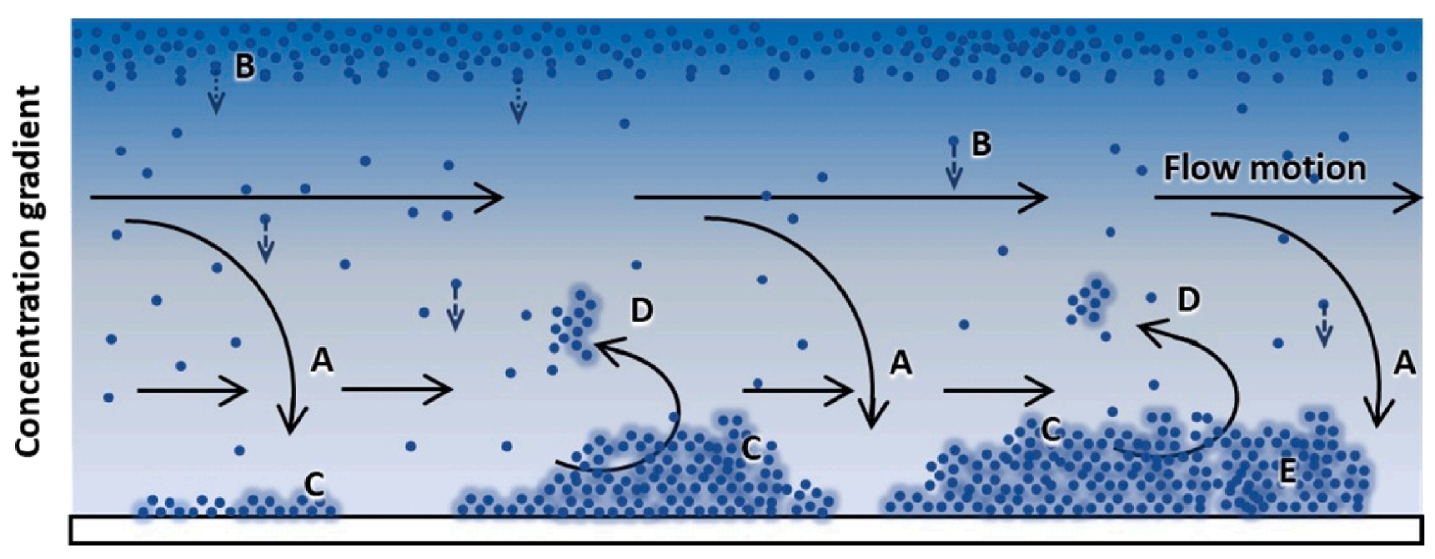

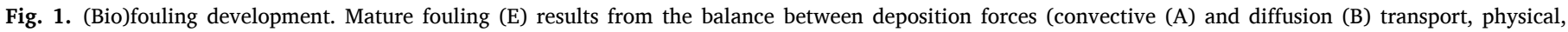
chemical and biological attachment (C)) and removal forces (shear effects, D). 
dissemination of contaminated aerosols [33,34]. Di Pippo et al. [35] reviewed the occurrence of biofouling in cooling water systems and the strategies for its monitoring and control. The most important control strategy is the use of oxidizing biocides, like chlorine, to maintain microbial populations below threshold values [36]. Thus, in these systems active microbial populations are always present, even if at low levels.

In the food industry, food matrixes and food processing surfaces are ideal substrata for biofouling formation with abundant organic load for microbial growth and maintenance. The main spoilage microorganisms are Bacillus cereus, Escherichia coli, Listeria monocytogenes, Salmonella enterica and Staphylococcus aureus [37]. These can survive and persist in biofouling, causing several adverse effects, like metal corrosion, reduction of product quality (e.g. changes in organoleptic properties and reduction of shelf life), and contamination of the final product. In fact, salmonellosis was the second most reported gastrointestinal infection in the European Union (EU). In 2017, 92649 confirmed cases were reported in $30 \mathrm{EU} /$ European Environment Agency (EEA) Member States, in which the main implicated food vehicles were poultry products (meat and eggs), powered milk and sesame paste [38]. Additionally, the European Food Safety Authority (EFSA) reported 2502 cases of listeriosis from ready-to-eat cold-smoked salmon, frozen corn and other frozen vegetables [39]. For example, biofilm formation in food industry infrastructures (in pre-cooking steps) is considered the main source of Salmonella enterica contamination [37].

Pulp and paper industries use large amounts of water, providing good conditions for microbial proliferation, and consequent biofouling development $[40,41]$. Related-biofouling concerns comprise undesired odour alterations (production of volatile substances), discolouration, loss of paper quality, possibility of explosions by formation of methane and hydrogen via anaerobic metabolism, and aerosol spread of pathogens [40]. To control that, high amounts of chemical biocides are applied to treat paper mill process water [42]. The main areas prone for biofouling development in paper and pulp industry facilities are wetends, coating sections, and the size emulsion [43]. For example, biofouling is usually found underneath the wire frame at the wet-end of the equipment as well as on the surface of foils, suction boxes, whitewater tanks and clarifiers.

Finally, biofouling also occurs in drinking water distribution systems $[26,44,45]$. Biofouling is responsible for compromising water quality (affecting taste, odour and colour), and cause pipe corrosion and discolouration [46]. The poor disinfection of drinking water, due to a lack of residual chlorine, is directly linked to waterborne outbreaks. Several waterborne outbreaks have been reported by the scientific community and Simões and Simões [47] reviewed some impacting waterborne outbreaks worldwide. For example, several outbreaks of hepatitis A virus were reported in the United States - 32 outbreaks with 857 total cases between 1971 and 2010 - mainly due to untreated or inadequately treated water [48]. In addition, in the Republic of Korea, in 2015, the mixing of contaminated groundwater with water supply caused a hepatitis A outbreak with 12 confirmed cases (1 death) [49]. In 2004, in Bergen (Norway), a giardiasis outbreak from contaminated drinking water caused 1300 confirmed cases [50].

\section{Industrial units}

Hydrodynamic conditions played in industrial units are usually characterized by the Reynolds number (Re, dimensionless) - the ratio between inertial and viscous forces. For fluid flow in piping settings (e.g. tubes in HEs and distribution networks), $R e$ is defined by Equation (1), where $v$ is the average flow velocity $(\mathrm{m} / \mathrm{s}), D$ is the characteristic length of the geometry (m) (inner diameter for circular cross-section tubes), $\rho$ and $\mu$ are fluid density $\left(\mathrm{kg} / \mathrm{m}^{3}\right)$ and dynamic viscosity $(\mathrm{kg} / \mathrm{m} \cdot \mathrm{s})$, respectively [25]. For stirred tanks, the impeller Reynolds number $\left(R e_{i}\right)$ is defined by Equation (2), where $\varpi$ is the angular velocity $(1 / \mathrm{s})$ and $D_{i}$ is the characteristic length of the geometry $(\mathrm{m})$ (impeller diameter for mechanically stirred tanks) [51].

$$
\begin{aligned}
& R e=\frac{\rho v D}{\mu} \\
& R e_{i}=\frac{\rho \varpi D_{i}^{2}}{\mu}
\end{aligned}
$$

The flow regime through a smooth pipe is defined as laminar $(R e<2100)$, transient $(2100<R e<10000)$ and fully turbulent (Re $>10000)$ [52]. For standard baffled mechanically stirred tanks, the flow is characterized as laminar $\left(R e_{i}<100\right)$, transient $(100<$ $\left.R e_{i}<10000\right)$ and fully turbulent $\left(R e_{i}>10000\right)$ [51]. The laminar flow is characterized by the absence of macroscopic mixing and a parabolic velocity field; turbulent flow reveals diverse flow instabilities with a chaotic movement; transient flow has intermediate properties between laminar and turbulent flows.

Other properties that describe the fluid flow are shear stress and shear rate. The shear stress $(\sigma=F / A$; Pa) is the tangential force $(F, \mathrm{~N})$ applied per unit area $\left(A, \mathrm{~m}^{2}\right)$; the shear rate $\left(\gamma=d v / d y ; \mathrm{s}^{-1}\right)$ is related to the fluid velocity $(v, \mathrm{~m} / \mathrm{s})$ in the perpendicular direction to the velocity $(y, \mathrm{~m})$ [52]. Both Newtonian (e.g. water, oil, milk) and non-Newtonian (e.g. polymer solutions, pulps, paints, emulsions) fluid flows are involved in industrial processes. For Newtonian fluids, shear stress is proportional to the shear rate $(\sigma=\mu \gamma)$. However, the shear rate of nonNewtonian fluids is not linearly proportional to the shear stress ( $\sigma=$ $\sigma_{0}+k \gamma^{n}$, for a Herschel-Bulkley fluid, as a general model) [52]. As the viscosity of non-Newtonian fluids depends on the local shear rate, the flow regime is distinct from Newtonian fluids - the most commonly studied [53]. Thus, the criteria for flow regime characterization based on $R e$ may fail when applied to non-Newtonian fluids [54]. Kfuri et al. [55] confirmed the similar behaviour of the friction factor as a function of $R e$ for Newtonian and non-Newtonian fluids. Thus, an accurate evaluation of flow regime of non-Newtonian fluids can require the knowledge of both $R e$ and friction factor [55].

Hydrodynamic conditions play an essential role in the process effectiveness and (bio)fouling phenomena in different industrial units mainly in HEs, distribution networks and stirred tanks. Tables 1-4 summarize reviewed values of $R e$, and shear stress or shear rate for each one, characterizing commonly used hydrodynamic conditions. A brief discussion of each industrial unit is provided to highlight the role of hydrodynamics in the process and in the equipment performance.

\subsection{Heat exchangers}

HEs are devices used to passively transfer heat from one hot fluid to a cold fluid, without direct contact or mixing between them. There are several types of HEs, designed for specific applications: concentric tube $\mathrm{HE}$, shell-and-tube HE, plate HE, shell-and-plate HE, among others. Recently, HE reactors have been considered as promising technologies for thermal control of exothermic reactions [56]. These allow fast mixing of reagents and temperature control, preventing undesirable generation of by-products [57]. The most commonly used has been the shell-and-tube HE, due to its high adaptability to distinct operating conditions and easy manufacturing [58-60]. For instance, shell-andtube HEs are widely used in food industry processes, particularly for evaporation, pasteurization, sterilization and refrigeration [61]. Although milk pasteurization could occur in a plate HE, that is more compact and suitable for low viscosity products [4]. The triple concentric tube $\mathrm{HE}$ may be an alternative to concentric tube $\mathrm{HE}$ as it is an improved version, with higher heat transfer area [62].

The hydrodynamic conditions in HEs influence the heat transfer coefficient: increasing fluid turbulence (high $R e$ ) enables a fast and homogeneous heat transfer; under laminar flow, heat transfer only occurs on the boundary layers, without uniformity at the centre. Thus, turbulent flows are desired for efficient HEs. In addition to high heat transfer efficiency, hydrodynamic conditions are involved in (bio)fouling formation with distinct properties, representing a major problem for in- 
Table 1

Hydrodynamic conditions in different types of heat exchangers (HEs).

\begin{tabular}{|c|c|c|c|}
\hline $\begin{array}{l}\text { Special operating } \\
\text { properties }\end{array}$ & Reynolds number & $\begin{array}{l}\text { Shear stress }(\mathrm{Pa}) \\
\text { Shear rate }(1 / \mathrm{s})\end{array}$ & Reference \\
\hline \multicolumn{4}{|l|}{ Tube HE } \\
\hline Buoyancy effects & $425-713$ & - & [89] \\
\hline $\begin{array}{l}\text { Equilateral triangular } \\
\text { cross-section } \mathrm{Al}_{2} \mathrm{O}_{3} / \\
\text { water } \mathrm{NF}\end{array}$ & $100-1000$ & - & {$[90,91]$} \\
\hline \multirow[t]{3}{*}{ Helically coiled tube } & $9000-19000$ & - & [80] \\
\hline & $3166-9658$ & - & [79] \\
\hline & $5000-12000$ & - & [92] \\
\hline $\mathrm{Al}_{2} \mathrm{O}_{3} /$ water NF & $500-1500$ & - & [84] \\
\hline Twisted aluminium tape & $3600-6100$ & - & [77] \\
\hline 2-dimensional ribs & $20000-60000$ & - & [69] \\
\hline Non-Newtonian fluid & $1000-4000$ & - & [93] \\
\hline $\begin{array}{l}\text { Aluminium nitride/ } \\
\text { ethylene glycol NF }\end{array}$ & $5000-17000$ & - & [86] \\
\hline $\begin{array}{l}\text { Functional multi-walled } \\
\text { carbon nanotube/water } \\
\text { NFBackward-facing step }\end{array}$ & 1-150 (inlet) & - & [94] \\
\hline Titania/water NF & $4500-14500$ & - & [95] \\
\hline $\begin{array}{l}\mathrm{Fe}_{3} \mathrm{O}_{4} / \text { water NFUnder } \\
\text { magnetic field }\end{array}$ & $250-2000$ & - & [64] \\
\hline $\mathrm{CuO} /$ water $\mathrm{NF}$ & $6200-14200$ & - & [81] \\
\hline $\begin{array}{l}\text { Elliptic tube } \\
\text { geometryInternal } \\
\text { longitudinal fins }\end{array}$ & $50-2000$ & - & [73] \\
\hline $\begin{array}{l}\text { Multi-walled carbon } \\
\text { nanotubes-iron oxide/ } \\
\text { water NFDiscrete } \\
\text { heating regions; ribs }\end{array}$ & $25-100$ & - & [70] \\
\hline U-bend & $100-2000$ & - & [96] \\
\hline $\mathrm{CuO} /$ ethylene glycol NF & $68-125.5$ & - & [97] \\
\hline $\begin{array}{l}\mathrm{SiO}_{2} / \text { ethylene glycol } \\
\text { NFBackward-facing step }\end{array}$ & 50-200 (inlet) & - & [98] \\
\hline Metal chains & $5000-15000$ & - & [76] \\
\hline $\begin{array}{l}\text { Cross-helix wall } \\
\text { corrugation }\end{array}$ & $50-14000$ & - & [9] \\
\hline \multicolumn{4}{|l|}{ Concentric tube HE } \\
\hline & $\begin{array}{l}\text { 17700-67700 } \\
\text { (annulus space) }\end{array}$ & - & [99] \\
\hline Rough surfaces & $\begin{array}{l}50-20000 \\
30000-248000 \\
\text { (annulus space) }\end{array}$ & - & {$[67,68]$} \\
\hline $\begin{array}{l}\text { Helically coiled } \\
\text { configuration } \mathrm{Al}_{2} \mathrm{O}_{3} / \\
\text { water } \mathrm{NF} ; \mathrm{SiO}_{3} / \text { water } \\
\mathrm{NF} ; \mathrm{CuO} / \text { water } \mathrm{NF}\end{array}$ & $11000-33000$ & - & [78] \\
\hline $\begin{array}{l}\text { Graphene nanoplatelet/ } \\
\text { industrial coolant NF }\end{array}$ & $3300-16500$ & - & [87] \\
\hline $\mathrm{CuO} /$ oil-water NF & $\begin{array}{l}19790-63830 \\
4500-13100 \\
\text { (annulus space) }\end{array}$ & - & [2] \\
\hline $\begin{array}{l}\text { Graphene nanoplatelets/ } \\
\text { ethylene glycol-water } \\
\text { NF }\end{array}$ & $3000-16000$ & $100-10001 / \mathrm{s}$ & [100] \\
\hline \multicolumn{4}{|l|}{ Triple concentric tube $\mathrm{HE}$} \\
\hline Non-Newtonian fluids & $\begin{array}{l}0.133 \\
2500-10900\end{array}$ & - & $\begin{array}{l}{[101]} \\
{[62]}\end{array}$ \\
\hline \multicolumn{4}{|l|}{ Shell-and-tube HE } \\
\hline $\begin{array}{l}\text { Continuous helical/ } \\
\text { Segmental baffles }\end{array}$ & $\begin{array}{l}\text { Tube side: }> \\
\text { 3000Shell side: } \\
580-2690\end{array}$ & - & [74] \\
\hline $\begin{array}{l}\text { Header sectionFouling } \\
\text { prevention }\end{array}$ & - & $\begin{array}{l}\text { Tube side: } \\
0.01-5.5 \mathrm{~Pa} \\
\text { (original setup) } \\
0.2-8 \mathrm{~Pa} \text { (flow } \\
\text { modifier) }\end{array}$ & [102] \\
\hline \multirow[t]{3}{*}{$\mathrm{Al}_{2} \mathrm{O}_{3} /$ water NF } & $\begin{array}{l}\text { Tube side: } \\
400-9000\end{array}$ & - & [88] \\
\hline & $\begin{array}{l}\text { Tube side: } \\
\text { 200-1800 }\end{array}$ & - & [82] \\
\hline & $\begin{array}{l}\text { Tube side: } \\
250-1200\end{array}$ & - & [103] \\
\hline $\begin{array}{l}\text { Circular/elliptical tube } \\
\text { geometries }\end{array}$ & $\begin{array}{l}\text { Tube side: } \\
\text { 4000-20000 }\end{array}$ & - & {$[104]$} \\
\hline
\end{tabular}

Table 1 (continued)

\begin{tabular}{|c|c|c|c|}
\hline $\begin{array}{l}\text { Special operating } \\
\text { properties }\end{array}$ & Reynolds number & $\begin{array}{l}\text { Shear stress }(\mathrm{Pa}) \\
\text { Shear rate }(1 / \mathrm{s})\end{array}$ & Reference \\
\hline Helical baffles & - & $\begin{array}{l}\text { Shell side: } 28-35 \\
\text { MPa (maximum) }\end{array}$ & [59] \\
\hline Segmental baffles & $\begin{array}{l}\text { Shell side: } \\
\text { 12000-28000 }\end{array}$ & - & [75] \\
\hline $\mathrm{Al}_{2} \mathrm{O}_{3}-\mathrm{Cu} /$ water hybrid NF & $\begin{array}{l}\text { Tube side: } \\
800-2400\end{array}$ & - & [58] \\
\hline \multicolumn{4}{|l|}{ Plate HE } \\
\hline $\begin{array}{l}\text { Herringbone pattern; } \\
\text { Trapezoid shape } \\
\text { corrugations; } \mathrm{CuO} / \text { water } \\
\text { NF }\end{array}$ & $\begin{array}{l}4100 \text { (hot water) } \\
50-1000 \text { (cold } \\
\text { NF) }\end{array}$ & - & [105] \\
\hline $\begin{array}{l}\text { Triangular shape } \\
\text { corrugations }\end{array}$ & $\begin{array}{l}8900-27650 \text { (cold } \\
\text { water) }\end{array}$ & $\begin{array}{l}2.1-13.3 \mathrm{~Pa} \text { (cold } \\
\text { water) }\end{array}$ & [106] \\
\hline Fouling effects & - & $\begin{array}{l}1-200 \mathrm{~Pa} \text { (cold } \\
\text { water) }\end{array}$ & [3] \\
\hline $\begin{array}{l}\text { Non-Newtonian fluid; } \\
\text { Turbulent flow Re }>260\end{array}$ & $\begin{array}{l}458-1171 \text { (cold } \\
\text { protein } \\
\text { concentrate) }\end{array}$ & - & [4] \\
\hline $\begin{array}{l}\text { Confined laminar radial } \\
\text { flow }\end{array}$ & $0-1400$ & - & [107] \\
\hline $\begin{array}{l}\text { Discrete heating regions; } \\
\text { Non-Newtonian NF }\end{array}$ & $50-300$ & - & [85] \\
\hline $\begin{array}{l}\mathrm{Al}_{2} \mathrm{O}_{3} / \text { water NF'Semi- } \\
\text { circular corrugations }\end{array}$ & $\begin{array}{l}10000-30000 \\
\text { (cold NF) }\end{array}$ & - & [71] \\
\hline $\begin{array}{l}\text { Chevron angle } 60^{\circ} \text { with a } \\
\text { symmetrical layout }\end{array}$ & $\begin{array}{l}50-350 \text { (hot } \\
\text { water) }\end{array}$ & - & [72] \\
\hline \multicolumn{4}{|l|}{ Shell-and-plate HE } \\
\hline & - & $\begin{array}{l}\text { 7-87 Pa (hot } \\
\text { side) } \\
\text { 89-187 Pa (cold } \\
\text { side) }\end{array}$ & [108] \\
\hline $\begin{array}{l}\text { Different cross-section area } \\
\text { for cold and hot sides }\end{array}$ & - & $\begin{array}{l}\text { 3-74 Pa (hot } \\
\text { side) } \\
\text { 89-257 Pa (cold } \\
\text { side) }\end{array}$ & [108] \\
\hline \multicolumn{4}{|l|}{ Multi-flow spiral-wound $\mathrm{HE}$} \\
\hline & $\begin{array}{l}\text { Tube side: } \\
\text { 30000-100000 }\end{array}$ & - & [109] \\
\hline \multicolumn{4}{|c|}{ Industrial milli-structured HE reactor } \\
\hline $\begin{array}{l}\text { Split-and-recombine } \\
\text { reactor }\end{array}$ & 40-5000 (water) & - & [57] \\
\hline $\begin{array}{l}\text { Corning HP (Heart Pattern) } \\
\text { reactor }\end{array}$ & $\begin{array}{l}350-1850 \text { (water) } \\
40-180 \text { (silicon } \\
\text { oils) } \\
15-63 \text { (glycerol) }\end{array}$ & - & [56] \\
\hline $\begin{array}{l}\text { Corning RT (Residence } \\
\text { Time) reactor }\end{array}$ & $\begin{array}{l}85-2000 \text { (water) } \\
25-170 \text { (silicon } \\
\text { oils) }\end{array}$ & - & [56] \\
\hline Chart reactor & $\begin{array}{l}200-3600 \text { (water) } \\
4-130 \text { (silicon } \\
\text { oils) }\end{array}$ & - & [56] \\
\hline
\end{tabular}

dustries using HEs [63]. Instead of increasing fluid velocity, passive and active methods have been applied to induce forced convection. Passive methods involve special surface geometries or flow additives to enhance heat transfer area or fluid conductivity, while active methods require an external power to generate electromagnetic fields and surface vibrations $[64,65]$. As passive devices are easily installed and no external energy supply is required, these have been commonly implemented as alternative to active devices [66]. Examples of passive methods are rough surfaces [67,68]; artificial roughness - ribs [69,70], corrugated surfaces [9,71,72], longitudinal fins [73]; extended surfaces - baffles [59,74,75]; swirl flow devices [76,77]; coiled tubes [78-80]; and flow additives as nanofluids (NF). NFs are produced by the addition of suspended nanoparticles (e.g. $\mathrm{CuO}, \mathrm{TiO}_{2}, \mathrm{Al}_{2} \mathrm{O}_{3}$, carbon nanotubes) in the base fluids ( $e$. g. ethylene glycol, oil, water) $[70,81,82]$. The combination of passive and active methods was studied by Malekan and Khosravi [64] that verified high heat transfer efficiency of ferrofluid (a NF) under increasing magnetic field.

The implementation of passive devices generates an early turbulence by complex velocity fields and secondary flow (e.g. fluid recirculation 
Table 2

Hydrodynamic conditions of hydraulic circuits.

\begin{tabular}{|c|c|c|}
\hline Special operating properties & Reynolds number & Reference \\
\hline \multicolumn{3}{|l|}{ Pipes } \\
\hline & 6876 & {$[121]$} \\
\hline Axial mixing of liquids & $30000-130000$ & [118] \\
\hline \multirow[t]{2}{*}{ Scale formation } & $12.5-158.5$ & [119] \\
\hline & $5-13500$ & [54] \\
\hline \multirow[t]{3}{*}{ Non-Newtonian fluid - pulp suspension } & $267-470900$ & {$[122,123]$} \\
\hline & $9500-22700$ & [124] \\
\hline & $500-3000$ & {$[125]$} \\
\hline \multirow[t]{2}{*}{ Helically coiled pipe } & $250-2500$ & [126] \\
\hline & 5046 & [127] \\
\hline Abrupt/sudden expansion & $100-1700$ (high diameter) & {$[120,128]$} \\
\hline Abrupt expansion/contractionNon- & 1-2000 (small diameter) & [55] \\
\hline Newtonian fluid & $\begin{array}{l}0.0005-250 \text { (small } \\
\text { diameter) }\end{array}$ & [110] \\
\hline $\mathrm{ZnO} /$ water rod-like $\mathrm{NF}$ & $2500-15000$ & [83] \\
\hline \multirow[t]{3}{*}{ Pulsating flow } & 22,000 & [129] \\
\hline & 82 & [130] \\
\hline & $236-4718$ & [65] \\
\hline Rectangular cross section & $80000-250000$ & [131] \\
\hline \multicolumn{3}{|l|}{ Elbow pipes - curved $90^{\circ}$ bend pipes } \\
\hline \multirow[t]{2}{*}{ Newtonian/non-Newtonian fluids } & $1000000-10000000$ & {$[111,132]$} \\
\hline & $100-1500$ & [133] \\
\hline Square cross section & $11500-115000$ & [112] \\
\hline \multicolumn{3}{|l|}{ Conical diffusers } \\
\hline Angle $2 \alpha=16^{\circ}$ & $37000-77000$ & [134] \\
\hline \multicolumn{3}{|l|}{ Orifice plates - Flowmeters } \\
\hline $\begin{array}{l}\text { Square-edged orifice plates } \\
\text { Newtonian/non-Newtonian fluids }\end{array}$ & $<4-6000$ & [53] \\
\hline Multi-hole orifice flow meter & $500-20000$ & [113] \\
\hline \multicolumn{3}{|l|}{ Valves - Flow controllers } \\
\hline Gate valve & $1000-30000$ & [12] \\
\hline Eccentric butterfly valve & $44000-1600000$ & [114] \\
\hline \multicolumn{3}{|l|}{ Static mixers } \\
\hline Corrugated static mixers & $34000-2500000$ & [115] \\
\hline Fractal perforated plate static mixer & $500-2000$ & {$[116]$} \\
\hline
\end{tabular}

and vortexes) from low velocities (low $R e$ ), that are typical for laminar flow. Mohebbi et al. [70] observed that increasing Re caused stronger vortexes behind the passive devices. Secondary flows appeared in helically coiled tubes due to an additional centrifugal force [79]. However, the increment in heat transfer efficiency is followed by an increase of friction loses and pressure drop, requiring high pumping power, that significantly increase the operating costs [80]. When compared with the other passive methods, wall corrugation produces low pressure drop [9].

According to the reviewed data about HEs (Table 1), heat transfer has been studied under different flow regimes: laminar flow, turbulent flow, and transition between the laminar and turbulent flows. All data is related to the strategies involved in enhancement of heat transfer effectiveness, including fluid turbulence, surface area, roughness, and thermal conductivity of working fluids. Most of the reviewed publications $(45 \%)$ are related to NFs, which have been considered the nextgeneration of working fluids [83]. NFs have high thermal conductivity improving heat transfer efficiency [84]. Raja et al. [82] found that heat transfer coefficient was dependent of the solid volume fraction: $0.5 \%$ and $1 \%(\mathrm{v} / \mathrm{v})$ of $\mathrm{Al}_{2} \mathrm{O}_{3} /$ water $\mathrm{NF}$ increased by $15 \%$ and $24 \%$ the convective heat transfer coefficient compared to water. Also, Li et al. [85] verified that increasing fluid velocity (high $R e$ ) increased the convective heat transfer coefficient. Similarly, Abdollahi-M. et al. [81] found high heat transfer for increasing $R e$ and volume fraction from $0 \%$ to $0.7 \%(\mathrm{v} / \mathrm{v}) \mathrm{CuO} /$ water NF. However, the heat transfer efficiency can be compromised for the highest volume fractions. For example, Hussein et al. [86] achieved $28 \%, 50 \%$ and $33 \%$ of heat transfer enhancement at $1 \%, 3 \%$ and $4 \%(\mathrm{v} / \mathrm{v})$ of aluminium nitride/ethylene glycol $\mathrm{NF}$, respectively. Furthermore, the high solid volume fraction of nanoparticles (high dynamic viscosity) and fluid velocity manage highpressure drop and pumping power requirements. Thus, the overall system efficiency should be optimized to achieve high heat transfer with minimum power requirements [87]. The early transition from laminar
Table 3

Hydrodynamic conditions in different configurations of stirred tank reactors (STRs) (concentric STR, eccentric STR, airlift reactor, annular reactor, and other specific geometries).

\begin{tabular}{|c|c|c|c|}
\hline Special operating properties & $\begin{array}{l}\text { Reynolds } \\
\text { number }\end{array}$ & $\begin{array}{l}\text { Shear stress }(\mathrm{Pa}) \\
\text { Shear rate }(1 / \mathrm{s})\end{array}$ & Reference \\
\hline \multicolumn{4}{|l|}{ Concentric STR } \\
\hline $\begin{array}{l}\text { Animal cell culture; Axial } \\
\text { impeller }\end{array}$ & $7350-22161$ & $1.21-1.611 / \mathrm{s}$ & [156] \\
\hline $\begin{array}{l}\text { Dissolution of pharmaceutical } \\
\text { bulk materials; Pitched } \\
\text { blade turbine, propeller, or } \\
\text { Ekato MIG }\end{array}$ & $400-144000$ & - & [51] \\
\hline $\begin{array}{l}\text { Non-Newtonian fluid; Rushton } \\
\text { turbine }\end{array}$ & $\begin{array}{l}975-9670 \\
0.1-20\end{array}$ & $\begin{array}{l}- \\
-\end{array}$ & $\begin{array}{l}{[136]} \\
{[158]}\end{array}$ \\
\hline $\begin{array}{l}\text { Synthesis of milk-clotting } \\
\text { protease by Centaurea } \\
\text { calcitrapa; Non-Newtonian } \\
\text { fluid; Marine propeller, } \\
\text { Rushton turbine }\end{array}$ & - & $\begin{array}{l}\text { 17-42 1/s } \\
\text { (maximum) }\end{array}$ & [149] \\
\hline $\begin{array}{l}\text { Non-Newtonian fluid; Gate } \\
\text { impeller }\end{array}$ & $0.7-415$ & - & {$[160,162]$} \\
\hline $\begin{array}{l}\text { Fermentation of lincomycin; } \\
\text { 3-Arrowy-blade disk turbine } \\
\text { (radial flow), Down-pump } \\
\text { propeller and 6-concave- } \\
\text { blade disk turbine (radial- } \\
\text { axial flow) }\end{array}$ & - & $0.64-27201 / \mathrm{s}$ & [157] \\
\hline $\begin{array}{l}\text { Bioethanol production; } \\
\text { Rushton turbine }\end{array}$ & $478-675$ & $\begin{array}{l}1.3-1.7 \mathrm{~Pa} \\
37-521 / \mathrm{s}\end{array}$ & [163] \\
\hline $\begin{array}{l}\text { Synthesis of proteases by } \\
\text { Jacaratia MexicanaRushton } \\
\text { turbine }\end{array}$ & - & $77-2741 / s$ & [155] \\
\hline Rushton turbine & $\begin{array}{l}300-30000 \\
32000-56000\end{array}$ & $\begin{array}{l}- \\
-\end{array}$ & $\begin{array}{l}{[161]} \\
{[150]}\end{array}$ \\
\hline $\begin{array}{l}\text { Solubilization of inclusion } \\
\text { bodies }\end{array}$ & $52-290$ & - & [139] \\
\hline $\begin{array}{l}\text { Non-Newtonian fluid; } \\
\text { Maxblend impeller }\end{array}$ & $7-68$ & - & [164] \\
\hline Pitched blade impeller & $10-10000$ & - & {$[165]$} \\
\hline $\begin{array}{l}\text { Process of sludge recovery; } \\
\text { Non-Newtonian fluid; } \\
\text { Anchor impeller }\end{array}$ & $<10$ & - & [159] \\
\hline $\begin{array}{l}\text { Bio-methanation digester for } \\
\text { biogas production; Lighthin } \\
\text { A310 impeller }\end{array}$ & $15000-80000$ & - & [138] \\
\hline $\begin{array}{l}\text { Synthesis of bioethanol by } \\
\text { Escherichia coli KO11; } \\
\text { Rushton turbine }\end{array}$ & $17600-18900$ & - & [151] \\
\hline $\begin{array}{l}\text { Cooling vessel; Non- } \\
\text { Newtonian fluid;Blade } \\
\text { impeller }\end{array}$ & $<1$ & - & [146] \\
\hline $\begin{array}{l}\text { Heating/cooling of liquids; } \\
\text { Rushton turbine, pitched } \\
\text { blade turbine }\end{array}$ & $2000-500000$ & - & [147] \\
\hline Rotating cylinder impeller & $4900-98000$ & - & [166] \\
\hline $\begin{array}{l}\text { Synthesis of active } \\
\text { pharmaceutical ingredients; } \\
\text { Retreat-blade impeller }\end{array}$ & $1-400000$ & - & [167] \\
\hline $\begin{array}{l}\text { Cooling crystallization; } \\
\text { Pitched blade turbine }\end{array}$ & $>10,000$ & $\begin{array}{l}\text { 30-70 Pa } \\
\text { (maximum) }\end{array}$ & [145] \\
\hline $\begin{array}{l}\text { Emulsification; Flat blade } \\
\text { impeller }\end{array}$ & - & $\begin{array}{l}417-11471 / \mathrm{s} \\
\text { (maximum) }\end{array}$ & {$[140]$} \\
\hline $\begin{array}{l}\text { Emulsification; Rushton } \\
\text { turbine, pitched blade } \\
\text { turbine }\end{array}$ & $24000-32000$ & - & [141] \\
\hline $\begin{array}{l}\text { Synthesis of clavulanic acid by } \\
\text { Streptomyces clavuligerus; } \\
\text { Non-Newtonian fluid }\end{array}$ & $\begin{array}{l}13,582 \\
\text { (maximum) }\end{array}$ & $\begin{array}{l}\text { 1.5-7.6 Pa } \\
\text { (maximum) } \\
\text { 4.92 } \mathrm{Pa} \text { (average) }\end{array}$ & [137] \\
\hline $\begin{array}{l}\text { Newtonian fluids with } \\
\text { different viscosity; Rushton } \\
\text { turbine, novel impeller } \\
\text { geometry }\end{array}$ & $10-1000$ & - & {$[142]$} \\
\hline $\begin{array}{l}\text { Animal cell culture; Three- } \\
\text { blade "Elephant Ears" } \\
\text { impeller, 3-blade propeller, } \\
\text { pitched blade turbine }\end{array}$ & $>21,000$ & $\begin{array}{l}2-181 / \mathrm{s} 1-61 / \mathrm{s} \\
\text { (bulk) } \\
1-71 / \mathrm{s} \\
\text { (average) }\end{array}$ & [152] \\
\hline
\end{tabular}

(continued on next page) 
Table 3 (continued)

\begin{tabular}{|c|c|c|c|}
\hline Special operating properties & $\begin{array}{l}\text { Reynolds } \\
\text { number }\end{array}$ & $\begin{array}{l}\text { Shear stress }(\mathrm{Pa}) \\
\text { Shear rate }(1 / \mathrm{s})\end{array}$ & Reference \\
\hline $\begin{array}{l}\text { Viscous Newtonian fluid; } \\
\text { Anchor impeller }\end{array}$ & $0.6-60$ & - & [143] \\
\hline \multicolumn{4}{|l|}{ Eccentric STR } \\
\hline Rushton turbine & $5000-11250$ & - & [168] \\
\hline $\begin{array}{l}\text { Polymerization reaction; } \\
\text { Rushton turbine, pitched } \\
\text { blade turbine }\end{array}$ & $9-40$ & - & [135] \\
\hline \multicolumn{4}{|l|}{ Airlift reactor } \\
\hline & - & $50-193001 / \mathrm{s}$ & [169] \\
\hline $\begin{array}{l}\text { Synthesis of proteases by } \\
\text { Jacaratia Mexicana }\end{array}$ & - & $361 / \mathrm{s}$ & [155] \\
\hline \multicolumn{4}{|c|}{ Annular reactor - Couette-Taylor reactor } \\
\hline Crystallization of triglycerides & - & $90-14401 / \mathrm{s}$ & [144] \\
\hline $\begin{array}{l}\text { Biofilm control } \\
\text { (hydrodynamic and } \\
\text { enzymatic treatment) }\end{array}$ & - & $\begin{array}{l}0.01 \mathrm{~Pa} \\
\text { (formation) } \\
0.01-8.5 \mathrm{~Pa} \\
\text { (treatment) }\end{array}$ & {$[170]$} \\
\hline \multirow{2}{*}{$\begin{array}{l}\text { Newtonian and non- } \\
\text { Newtonian fluids;Annular } \\
\text { flow instabilities }\end{array}$} & $10-200$ & - & [171] \\
\hline & $500-8000$ & - & [172] \\
\hline Bacterial adhesion & $5000-72000$ & $\begin{array}{l}0.09-7.3 \mathrm{~Pa} \\
86-73001 / \mathrm{s}\end{array}$ & [173] \\
\hline \multirow[t]{2}{*}{$\begin{array}{l}\text { Newtonian and non- } \\
\text { Newtonian fluid }\end{array}$} & $120-1000$ & - & [174] \\
\hline & $5770-6924$ & - & [175] \\
\hline $\begin{array}{l}\text { Crystallization of trimesic acid } \\
\text { Other geometries }\end{array}$ & $<2$ & $0-1671 / \mathrm{s}$ & [176] \\
\hline $\begin{array}{l}\text { Pressure-cycle driven } \\
\text { miniaturized bioreactor; } \\
\text { Production of human IgG by } \\
\text { Chinese Hamster Ovary } \\
\text { (CHO) cells }\end{array}$ & - & $\begin{array}{l}0.18 \mathrm{~Pa} \\
\text { (maximum) }\end{array}$ & [153] \\
\hline $\begin{array}{l}\text { Small-scale eccentrical stirred } \\
\text { tank bioreactor; Angled-disc } \\
\text { impeller }\end{array}$ & $0.1-416$ & - & [154] \\
\hline $\begin{array}{l}\text { Bubble column; Synthesis of } \\
\text { proteases by Jacaratia } \\
\text { Mexicana }\end{array}$ & - & $131 / s$ & [155] \\
\hline $\begin{array}{l}\text { Electoflotation column - } \\
\text { wastewater treatment; } \\
\text { Rushton turbine }\end{array}$ & $2000-20000$ & - & [177] \\
\hline $\begin{array}{l}\text { 2D rocking-motion single-use } \\
\text { bioreactor; Synthesis of } \\
\text { clavulanic acid by } \\
\text { Streptomyces clavuligerus; } \\
\text { Non-Newtonian fluid }\end{array}$ & $\begin{array}{l}15896 \\
\text { (maximum) }\end{array}$ & $\begin{array}{l}0.07-0.75 \mathrm{~Pa} \\
\text { (maximum) } \\
0.44 \mathrm{~Pa} \text { (average) }\end{array}$ & [137] \\
\hline
\end{tabular}

to turbulent flow for NFs can ensure fluid turbulence under lower Re, without penalty on heat transfer and pressure drop [88].

\subsection{Fluid distribution networks}

In industrial facilities, all the fluids are distributed by hydraulic circuits, that have different components, such as pipes $[65,83]$, sudden or abrupt contractions and expansions [55,110], elbows [111,112], flow meters and controllers [113,114], static mixers [115,116], tees, bends and pumps. Due to surface colonization by microorganisms, biofouling development in these systems is inevitable with more persistence in regions characterized by low hydrodynamics. In fact, abrupt changes in process flow rate could cause biofouling detachment and consequent contamination of final product [117]. According to the reviewed data about hydrodynamic conditions through pipes and singularities in distribution networks (Table 2), the fluid distribution has been performed typically under turbulent conditions. Laminar flow has been studied at a small extent for specific applications, like buoyancy effects (main driving force in mass transfer under low $R e$ ) [118], fouling development [119], contraction and expansion sections $[55,110,120]$.

The singularities in distribution networks cause higher turbulence and pressure drop than in a classical pipe, due to changes in the velocity
Table 4

Hydrodynamic conditions in other industrial units: solar collectors and other processes.

\begin{tabular}{|c|c|c|c|}
\hline Special operating properties & $\begin{array}{l}\text { Reynolds } \\
\text { number }\end{array}$ & $\begin{array}{l}\text { Shear stress }(\mathrm{Pa}) \\
\text { Shear rate }(1 / \mathrm{s})\end{array}$ & Reference \\
\hline \multicolumn{4}{|l|}{ Solar collectors } \\
\hline $\begin{array}{l}\text { Tubular photobioreactor; } \\
\text { Different cross sections }\end{array}$ & $12677-25354$ & $0.44-3.43 \mathrm{~Pa}$ & [187] \\
\hline $\begin{array}{l}\text { Flat-plane airlift } \\
\text { photobioreactor }\end{array}$ & 978-1956 & - & [186] \\
\hline Flat-plate solar water collector & $400-2500$ & - & [183] \\
\hline $\begin{array}{l}\text { Flat-plate solar water collector; } \\
\text { Longitudinal vortex } \\
\text { generator }\end{array}$ & $300-900$ & - & [184] \\
\hline Plane tube solar collector & $\begin{array}{l}4121-5326 \\
\text { (water) } \\
1-7\left(\mathrm{TiO}_{2} /\right. \\
\text { water } \mathrm{NF} \text { ) }\end{array}$ & - & [185] \\
\hline \multicolumn{4}{|l|}{ Other applications } \\
\hline $\begin{array}{l}\text { Cooling water system; Rotating } \\
\text { disk electrode }\end{array}$ & $0-8434$ & $0-1.62 \mathrm{~Pa}$ & [180] \\
\hline $\begin{array}{l}\text { Phosgenation reaction; Flow } \\
\text { reactor system with T-shaped } \\
\text { mixers }\end{array}$ & $21-7852$ & - & {$[182]$} \\
\hline $\begin{array}{l}\text { Recrystallization of oil- } \\
\text { dispersed micronized fat } \\
\text { crystal nanoplatelets; Stirred } \\
\text { bowl }\end{array}$ & - & $1-101 / \mathrm{s}$ & [179] \\
\hline $\begin{array}{l}\text { Convective heat transfer in } \\
\text { porous media (rod bundles, } \\
\text { transpiration cooling and } \\
\text { fluidized beds); Regular } \\
\text { porous structure of a periodic } \\
\text { staggered array of square } \\
\text { cylinders }\end{array}$ & $500-2000$ & - & {$[188]$} \\
\hline $\begin{array}{l}\text { Dynamic mixer; Laminar lid- } \\
\text { driven cavity flow }\end{array}$ & 12.7 & - & [189] \\
\hline $\begin{array}{l}\text { Fluidisation and catalysis; } \\
\text { Packed bed of rod-like } \\
\text { particles }\end{array}$ & $150-350$ & - & [190] \\
\hline $\begin{array}{l}\text { Alkaline water electrolysis; 3-D } \\
\text { nickel electrodes }\end{array}$ & $1400-2700$ & - & [181] \\
\hline
\end{tabular}

fields and induction of mixing [132]. For example, in curved pipes (e.g. elbows, U-bends, coiled tubes), secondary flows are imposed by the action of an additional centrifugal force [96]. Even under laminar flow, flow disturbances are higher for increasing $R e$. In sudden contraction or expansion sections, the fluid velocity is affected by changing the pipe diameter [134]. Georgantopoulou [128] verified that longer recirculation zones occurred for increasing $R e$ in an abrupt expansion. Other devices that generate turbulent-like flow are static mixers that promote a continuous mixing inside the pipe using the flow energy, instead of using mechanically stirred tanks $[115,116]$. Thus, all increased pressure drop in distribution network must be overcome by the pumping power.

\subsection{Stirred tanks}

Mixing in industrial facilities is carried out typically in stirred tanks. These devices ensure the ideal mixing conditions needed for several industrial applications, like chemical reactions [135,136], biological process [137,138], dissolution [51,139], emulsification [140,141], homogenization [142,143], crystallization [144,145], heating and cooling processes $[146,147]$. In fact, stirred tanks are less prone to develop biofouling than the systems described above. However, poor cleaning and disinfection in low access areas can involve unwanted debris and microbial accumulation, leading to biofouling formation and possible reduction of product quality [148].

The desired characteristics of final products are strongly influenced by the operating mixing conditions. For example, the particle size distribution in the crystallization of paracetamol was improved by controlling the nucleation kinetics through hydrodynamics [145]. The 
droplet sizes of an emulsion depended on hydrodynamic conditions of its production: the droplets size decreased as the $R e$ increased, due to its high breakup [141]. Also, Raposo and Lima-Costa [149] verified that the productivity of a biological process (protease production by plant cells) was influenced by high oxygen transfer and bulk mixing, avoiding high shear stress. In general, the ideal process conditions are achieved for a small scale, being scale-up performed while maintaining a specific set of parameters constant. Common parameters are related to hydrodynamics like mixing time, stirrer speed, and oxygen mass transfer coefficient $[150,151]$. However, several authors have demonstrated heterogeneous hydrodynamic fields in mechanically stirred tank reactors (STRs): high shear stresses near to the impeller blade and low ones in the bulk fluid $[141,152]$. Miniaturized bioreactors have been designed to improve the scale-up with hydrodynamic conditions closer to the conventional STR [153,154].

In general, the ideal operating conditions for biological processes in STRs comply an efficient mass and heat transfer and good bulk mixing [149]. Mixing performance enhances with increasing stirrer speed, but mechanical constraints are created by high shear stress, resulting in changes on the cell phenotype and morphology [149]. Thus, when involving shear-sensitive cells, like mammalian [153], filamentous [137] and plant cells [155], a balance between the best bulk mixing and acceptable cell damage must be considered [156]. The implementation of a multiple-impeller system instead of a singular one has shown good mixing conditions, with reduced shear stress $[149,157]$. The selection of a reactor geometry (e.g. STR, bubble column and airlift reactor) that involves distinct hydrodynamic conditions also affects biological processes [155].

According to the reviewed data about hydrodynamics played in stirred tanks (Table 3), STRs have been the most studied (67\%). The main goal of these studies has been the optimization of hydrodynamic conditions with efficient mixing and reduction of power requirements. The typical fluid flow inside stirred tanks is turbulent; only a few studies have applied laminar flow (37\%). The viscous Newtonian fluids and non-Newtonian fluids (high viscosity and solid-like behaviour) have been mainly studied under laminar flow since the mixing power requirements are independent of fluid viscosity under fully turbulent flows [146,158-160]. Scargiali et al. [161] verified that the best mixing efficiency occurred for the least viscous fluid under high stirrer speed, and the power requirements increased with fluid viscosity.

The hydrodynamic conditions in STRs mainly depend on the impeller design and size, tank geometry and fluid properties. The impeller is responsible for fluid mixing, promoting radial flow (from the central axis out to the sides of the tank and back again) and/or axial flow (up and down the height of the vessel) [178]. Different impeller designs, like blade inclination and geometrical modifications, cause different mixing performance and power consumption [143,160]. Jaszczur et al. [142] proposed a new impeller shape with reduced power consumption for the same or better mixing level when compared to the Rushton turbine. Several singularities in STRs (e.g. eccentrical agitation, baffles, aeration) induce the formation of macro-instabilities (chaotic velocity fields) that influence the hydrodynamics, increasing the turbulence level and reducing the power requirements [168]. The agitation in STR is usually concentric (agitator shaft centrally located), but the eccentrical agitation (off-centred agitator shaft) has demonstrated better mixing performances under laminar flow [135,154]. In fact, concentric agitation (mainly radial flow) under laminar flow divides the fluid bulk into two independent compartments and a central vortex is created under high stirrer speeds [167]. While the eccentrical agitation disrupts the fluid symmetry and compartmentalization phenomena, promoting the axial flow and increasing turbulence [135]. On the other hand, the use of baffles in tank walls inhibits vortex formation and improves the mixing conditions [161]. In addition, baffling can reduce power requirement of agitation under turbulent flow, without influence under laminar flow [167].

\subsection{Other industrial units}

Other units used in industrial facilities covered by this review are presented in Table 4, as solar collectors (water solar collectors and photobioreactors), and other processes where hydrodynamics plays an important role, such as crystallization [179], corrosion inhibition in cooling water systems [180], hydrogen production by alkaline water electrolysis [181], and chemical reactions in a flow reactor system [182]. Water solar collectors can be considered as specific HEs that use solar radiant energy as heating source. Thus, the reviewed studies focused on increasing heat transfer efficiency using passive methods, such as twisted taps and wire-coils [183], swirl flow devices [184], and NFs [185]. On the other hand, photobioreactors using solar radiant energy for phototrophic microbial growth are affected by both high aperture area and hydrodynamic conditions [186], and shear stress needs to be managed to result in a positive balance between high biomass production and low cell damage [187].

\section{Hydrodynamics on (bio)fouling prevention and control}

In industrial settings, turbulent flow (high shear stress) is typical in many process units. For example, the use of $1.5 \mathrm{~m} / \mathrm{s}(R e>3000)$ is recommended in dairy manufacturing plants [191] and 1.5 to $3 \mathrm{~m} / \mathrm{s}$ in HEs, to reduce biofouling [192]. Typical Re values range between $10^{2}$ and $10^{4}$, corresponding to transient and turbulent flow conditions (Tables 1-4). However, even under these conditions, due to equipment design constrains, some regions are characterized by a low flow rate, recirculation, and fluid stagnation (low $R e$ ) - called as dead-end zones. The lowest value reported for shear stress in these critical areas was $0.01 \mathrm{~Pa}$ [102]. The low shear stress allows the initial deposition and consequent fouling formation [193]. In fact, Simunic et al. [44] verified that in dead-end zones, fouling was not affected by fluid flushing (high turbulence from high fluid velocity) that was typical for the main pipe. Several studies identified critical areas for fouling formation such as the regions closed to corners and baffles $[59,75,104]$ and header section [102] in HE, regions closed to expansions/contractions [110,120], angles [128,134], elbows [112,133], and valves [12,114] in distribution networks, and regions closed to corners in the bottom [154], and baffles in the tank wall [165] in STRs. In addition of being prone for fouling phenomena, dead-end zones affect CIP efficacy, compromising the process and product quality, and increase operating and maintenance costs [12].

As the study of biofouling in real industrial settings is difficult, several devices have been developed for biofouling formation and testing of control strategies. Table 5 summarizes conditions reported in studies about industrial biofouling formation and control (covering publications between 2010 and 2020). In general, industrial biofilm studies have been managed under static conditions (57\% - Table I in the supplementary material) without considering the impact of hydrodynamics. However, under controlled industrial mimicking conditions, it is realistic to interpolate tangible facts that may influence biofouling development in industrial settings. Therefore, commonly used devices for biofouling studies are the flow cell $[11,44,194]$, rotating disk reactor $[195,196]$, rotating cylinder reactor $[197,198]$, and microtiter plates $[199,200]$. Many other devices have been used for biofouling studies as already reviewed by Gomes et al. [26].

According to several authors, biofouling development in industrial settings depends on the hydrodynamic conditions, which will determine the structure and behaviour of the bio-deposit $[13,197,201]$. The initial stage for biofouling is characterized by the deposition and adhesion of particles and microorganisms to surfaces. This stage is influenced by the hydrodynamic conditions, resulting in distinct distribution patterns from a single cell to clusters under low and high shear stress, respectively $[13,173]$. Adhesion is higher when increasing fluid velocity (high diffusion transport), until a value that promotes surface erosion, hindering biofouling development [202]. However, even under high shear 
Table 5

Hydrodynamic conditions used different studies of (bio)fouling formation/control with potential translational relevance for the industry. Legend: biofilm age (time) in hour(s), h; day(s), d; week(s), w; month(s), m. Hydrodynamic conditions are summarized as agitation speed (rpm), flow rate (L/s), fluid velocity (m/s), shear stress (Pa) and/or Reynolds number (Re).

\begin{tabular}{|c|c|c|c|c|c|c|}
\hline Industrial system & Microorganisms & System & Time & $\begin{array}{l}\text { Hydrodynamic } \\
\text { conditions }\end{array}$ & Main goal & Reference \\
\hline \multirow[t]{24}{*}{$\begin{array}{l}\text { Fundamental academic } \\
\text { study }\end{array}$} & Escherichia coli & $\begin{array}{l}\text { Glass coupons;96-well } \\
\text { polystyrene (PS) microtiter } \\
\text { plates }\end{array}$ & $24-72 \mathrm{~h}$ & 50 rpm; Static & $\begin{array}{l}\text { Biofilm formation by a model } \\
\text { organism for multicellular } \\
\text { bacterial research }\end{array}$ & [213] \\
\hline & E. coli & $\begin{array}{l}\text { Flow cell with stainless steel } \\
\text { (SS) and titanium coupons }\end{array}$ & $18 \mathrm{~h}$ & $\begin{array}{l}5 \mathrm{~mL} / \mathrm{min}\left(8 \times 10^{-2}\right. \\
\mathrm{m} / \mathrm{s})\end{array}$ & Continuous biofilm monitoring & [214] \\
\hline & Staphylococcus epidermidis & $\begin{array}{l}\text { Graphitic carbon nitride } \\
\text { coupons }\end{array}$ & $1+3 d$ & Static $+80 \mathrm{rpm}$ & $\begin{array}{l}\text { Biofilm control by } \\
\text { photocatalysis under visible- } \\
\text { light irradiation }\end{array}$ & {$[215]$} \\
\hline & Heterotrophic bacteria & $\begin{array}{l}\text { Biofilm Annular Reactor } \\
\text { with nano benzalkonium } \\
\text { chloride and nano silver } \\
\text { sulfadiazine coated SS } \\
\text { coupons }\end{array}$ & $4 \mathrm{~m}$ & - & $\begin{array}{l}\text { Biofilm control by } \\
\text { nanotechnological biocides }\end{array}$ & [216] \\
\hline & Burkholderia terricola & $\begin{array}{l}\text { Poly( } \varepsilon \text {-caprolactone }) \\
\text { nanofibres }\end{array}$ & $30 \mathrm{~h}$ & $80 \mathrm{rpm}$ & $\begin{array}{l}\text { Effects of polymer nanofibers } \\
\text { on biofilm formation }\end{array}$ & [217] \\
\hline & Pseudomonas aeruginosa & $\begin{array}{l}\text { Centre for Disease Control } \\
\text { Biofilm reactor with SS } \\
\text { coupons }\end{array}$ & $18 \mathrm{~h}$ & $11.7 \mathrm{~mL} / \mathrm{min}$ & $\begin{array}{l}\text { Biofilm control by cold } \\
\text { atmospheric-pressure plasma } \\
\text { (CAP) }\end{array}$ & [218] \\
\hline & $\begin{array}{l}\text { E. coli } \\
\text { P. aeruginosa } \\
\text { Staphylococcus aureus }\end{array}$ & $\begin{array}{l}\text { Glass coupons; 96-well PS } \\
\text { microtiter plates }\end{array}$ & $24-48 \mathrm{~h}$ & - & Biofilm control by fumigation & [219] \\
\hline & E. coli & $\begin{array}{l}\text { Nanocrystalline diamond } \\
\text { films on glass and silicon } \\
\text { coupons }\end{array}$ & $48 \mathrm{~h}$ & $80 \mathrm{rpm}$ & $\begin{array}{l}\text { Biofilm prevention by modified } \\
\text { surfaces }\end{array}$ & {$[220]$} \\
\hline & E. coliS. aureus $P$. aeruginosa & $\begin{array}{l}\text { Calgary Biofilm Device/ } \\
\text { MBEC }^{\mathrm{TM}}\end{array}$ & $48 \mathrm{~h}$ & $150 \mathrm{rpm}$ & $\begin{array}{l}\text { Dual-species biofilm control by } \\
\text { silver oxynitrate }\end{array}$ & {$[221]$} \\
\hline & Shewanella putrefaciens & $\begin{array}{l}\text { 96-well PS microtiter plates; } \\
\text { Multichannel flow cell } \\
\text { system with glass coupons }\end{array}$ & $24-48 \mathrm{~h}$ & $\begin{array}{l}\text { Static } \\
12 \mathrm{~mL} / \mathrm{h}\end{array}$ & $\begin{array}{l}\text { Biofilm prevention by sodium } \\
\text { lactate }\end{array}$ & {$[222]$} \\
\hline & P. aeruginosa & $\begin{array}{l}\text { Borosilicate bottles; Drip } \\
\text { flow reactor with glass } \\
\text { coupons }\end{array}$ & $\begin{array}{l}24 \mathrm{~h} 24+ \\
48 \mathrm{~h}\end{array}$ & $\begin{array}{l}\text { Static } \\
\text { Static }+18 \mathrm{~mL} / \mathrm{h}\end{array}$ & $\begin{array}{l}\text { Biofilm control by lauroyl } \\
\text { arginate ethyl }\end{array}$ & {$[223]$} \\
\hline & P. aeruginosa & $\begin{array}{l}\text { 96-well PS microtiter plates; } \\
\text { Drip flow reactor with glass } \\
\text { coupons }\end{array}$ & $\begin{array}{l}24 \mathrm{~h} 24+ \\
24 \mathrm{~h}\end{array}$ & $\begin{array}{l}\text { Static } \\
\text { Static }+20 \mathrm{~mL} / \mathrm{h}\end{array}$ & Biofilm prevention by raffinose & [224] \\
\hline & E. coli & $\begin{array}{l}\text { CDC Biofilm Reactor with } \\
\text { modified polyethylene (PE) } \\
\text { terephthalate (PET) coupons }\end{array}$ & $2 \mathrm{~d}$ & $\begin{array}{l}125 \text { rpm(high } \\
\text { shear stress) }\end{array}$ & $\begin{array}{l}\text { Effects of laser surface } \\
\text { modification on biofilm } \\
\text { formation }\end{array}$ & {$[225]$} \\
\hline & $\begin{array}{l}\text { Acinetobacter baumannii } \\
\text { P. aeruginosa } \\
\text { Serratia marcescens } \\
\text { Providencia stuartii }\end{array}$ & $\begin{array}{l}\text { Glass couponsThree-channel } \\
\text { flow cells with glass, glass } \\
\text { covered with polyaccharide } \\
\text { and Cu- metal complex films } \\
\text { (MCF) coupons }\end{array}$ & $24 \mathrm{~h} 48 \mathrm{~h}$ & $\begin{array}{l}\text { Static } \\
3 \mathrm{~mL} / \mathrm{h} \text { (laminar) }\end{array}$ & $\begin{array}{l}\text { Biofilm prevention by modified } \\
\text { surface derived from a } \\
\text { microalgal polysaccharide }\end{array}$ & {$[226]$} \\
\hline & S. putrefaciens & Glass tubes & $12 \mathrm{~h}$ & $100 \mathrm{rpm}$ & $\begin{array}{l}\text { Role of FlrA on the signalling } \\
\text { pathway from DosD-derive c- } \\
\text { di-GMO to BpfA-associated } \\
\text { biofilm formation }\end{array}$ & [227] \\
\hline & $\begin{array}{l}\text { Candida parapsilosis } \\
\text { Candida krusei }\end{array}$ & 96-well PS microtiter plates & $24-48 \mathrm{~h}$ & $150 \mathrm{rpm}$ & $\begin{array}{l}\text { Application of Cellavista device } \\
\text { for evaluation of biofilm } \\
\text { control by antifungal agents }\end{array}$ & {$[228]$} \\
\hline & Bacillus cereus & $\begin{array}{l}\text { Rotating cylinder reactor } \\
\text { with SS cylinders }\end{array}$ & $7 \mathrm{~d}$ & $\begin{array}{l}\mathrm{Re}=1000-4000 \\
(0.02-0.17 \mathrm{~Pa})\end{array}$ & $\begin{array}{l}\text { Effects of shear stress on } \\
\text { biofilm formation and control }\end{array}$ & [197] \\
\hline & Listeria monocytogenes & $\begin{array}{l}\text { 96-well PS microtiter plates; } \\
\text { Flow cell system with glass } \\
\text { coupons }\end{array}$ & $\begin{array}{l}24-51 h \\
3-4 d\end{array}$ & $\begin{array}{l}\text { Static } \\
3 \mathrm{~mL} / \mathrm{h}\end{array}$ & $\begin{array}{l}\text { Effects of extracellular DNA on } \\
\text { biofilm formation }\end{array}$ & [229] \\
\hline & P. aeruginosa spp. & $\begin{array}{l}\text { Flow cell chambers; } \\
\text { Microscopy chamber system }\end{array}$ & $\begin{array}{l}4-5 d \\
1 d\end{array}$ & $0.0055 \mathrm{~m} / \mathrm{sStatic}$ & $\begin{array}{l}\text { Rheological impact of } \\
\text { exopolysaccharides on biofilm }\end{array}$ & [230] \\
\hline & E. coli & $\begin{array}{l}\text { Flow cell reactor with } \\
\text { polyvinyl chloride (PVC) } \\
\text { coupons }\end{array}$ & $9 \mathrm{~d}$ & $\begin{array}{l}242-374 \mathrm{~L} / \mathrm{h}(\mathrm{Re}= \\
4350-6720 \\
0.183-0.511 \mathrm{~Pa})\end{array}$ & $\begin{array}{l}\text { Effects of flow rate on biofilm } \\
\text { formation }\end{array}$ & [231] \\
\hline & P. aeruginosa & $\begin{array}{l}\text { Multichannel microdevice } \\
\text { flow system with a 9-chan- } \\
\text { nel SS flow chamber }\end{array}$ & $7 \mathrm{~d}$ & $11 \mathrm{~mL} / \mathrm{h}$ & $\begin{array}{l}\text { Effects of nutrient load on } \\
\text { biofilm architecture }\end{array}$ & {$[232]$} \\
\hline & B. cereus & SS coupons & $2-24 \mathrm{~h}$ & $120 \mathrm{rpm}$ & $\begin{array}{l}\text { Effects of surface properties on } \\
\text { biofilm formation }\end{array}$ & [233] \\
\hline & $\begin{array}{l}P . \text { aeruginosa } \\
\text { S. aureus } \\
\text { E. coli }\end{array}$ & $\begin{array}{l}\text { Flow cell system with } \\
\text { slippery liquid-infused } \\
\text { porous surfaces }\end{array}$ & $24-7 \mathrm{~d}$ & - & $\begin{array}{l}\text { Biofilm prevention by modified } \\
\text { surfaces }\end{array}$ & {$[234]$} \\
\hline & $\begin{array}{l}\text { E. coli } \\
\text { S. aureus }\end{array}$ & $\begin{array}{l}\text { Flow cell system with zinc } \\
\text { oxide coated and uncoated } \\
\text { glass coupons }\end{array}$ & $24 \mathrm{~h}$ & $10 \mathrm{~mL} / \mathrm{h}$ & $\begin{array}{l}\text { Biofilm prevention by modified } \\
\text { surfaces }\end{array}$ & [235] \\
\hline
\end{tabular}


Table 5 (continued)

\begin{tabular}{|c|c|c|c|c|c|c|}
\hline Industrial system & Microorganisms & System & Time & $\begin{array}{l}\text { Hydrodynamic } \\
\text { conditions }\end{array}$ & Main goal & Reference \\
\hline & E. coli & $\begin{array}{l}\text { Flow cell reactor with PVC } \\
\text { coupons }\end{array}$ & $13 \mathrm{~d}$ & $\begin{array}{l}350 \mathrm{~L} / \mathrm{h}(\mathrm{Re}= \\
6290)\end{array}$ & Biofilm formation & [236] \\
\hline & Rhodotorula mucilaginosa & $\begin{array}{l}\text { Biofilm reactor with } \\
\text { polypropylene (PP) coupons }\end{array}$ & $1-13 \mathrm{~d}$ & $95 \mathrm{rpm}$ & Yeast biofilm formation & {$[237]$} \\
\hline & Vibrio algynolyticus & $\begin{array}{l}\text { Galvanized coupons with } \\
\text { and without oxide } \\
\text { incorporation }\end{array}$ & $\begin{array}{l}24-1404 \\
\mathrm{~h}\end{array}$ & Laminar & $\begin{array}{l}\text { Biofilm prevention by coated } \\
\text { surfaces }\end{array}$ & [238] \\
\hline & Vibrio cholerae & 96-well PS microtiter plates; & $24 \mathrm{~h}$ & Static & Biofilm prevention by a novel & [239] \\
\hline & P. aeruginosa & Flow cell system & $24-48 \mathrm{~h}$ & $0.15-0.2 \mathrm{~mL} / \mathrm{min}$ & benzimidazole & \\
\hline & Klebsiella pneumoniae & & & & & \\
\hline & Erwinia amylovora & & & & & \\
\hline & Shigella boydii & & & & & \\
\hline & S. aureus & & & & & \\
\hline & Pseudomonas putida & $\begin{array}{l}\text { Flow cell system with SS } \\
\text { coupons }\end{array}$ & $1-12 \mathrm{~d}$ & $120 \mathrm{~mL} / \mathrm{h}$ & Biofilm detection & {$[240]$} \\
\hline & $\begin{array}{l}\text { Pseudomonas fluorescens } \\
\text { P. aeruginosa }\end{array}$ & $\begin{array}{l}\text { Continuous-flow reactor } \\
\text { system: Carbon dioxide } \\
\text { evolution measurement } \\
\text { system }\end{array}$ & $54 \mathrm{~h}$ & $15 \mathrm{~mL} / \mathrm{h}$ & $\begin{array}{l}\text { Influence of strain origin and } \\
\text { nutrient concentration in } \\
\text { biofilm formation }\end{array}$ & {$[241]$} \\
\hline \multirow[t]{12}{*}{ Food industry } & Salmonella enterica & 96-well PS microtiter & 1 & StaticIn situ & Biofilm removal by enzyme & [242] \\
\hline & S. aureus & platesKitchen drainage pipe & dNatural & & cocktail produced by Aspergillus & \\
\hline & E. coli & section & slime & & niger & \\
\hline & $\begin{array}{l}\text { From a minimally processed } \\
\text { vegetables plant }\end{array}$ & 96-well PS microtiter plates & $24 \mathrm{~h}$ & $120 \mathrm{rpm}$ & Biofilm formation & [243] \\
\hline & E. coli & $\begin{array}{l}\text { Flow cell system with } \\
\text { modified Diamond-like } \\
\text { carbon surface (SICON) and } \\
\text { SS coupons }\end{array}$ & $1-5 d$ & $\begin{array}{l}300 \mathrm{~L} / \mathrm{h} \\
(0.25 \mathrm{~Pa})\end{array}$ & $\begin{array}{l}\text { Effects of SICON }{ }^{\circledR} \text { surfaces on } \\
\text { biofilm prevention and control }\end{array}$ & [244] \\
\hline & P. fluorescens & $\begin{array}{l}\text { Flow cell system with SS } \\
\text { coupons }\end{array}$ & $12 \mathrm{~d}$ & $\begin{array}{l}3.4 \mathrm{~L} / \mathrm{h} \\
(\operatorname{Re}=4000)\end{array}$ & $\begin{array}{l}\text { Biofilm control by brominated } \\
\text { and chlorinated chemicals }\end{array}$ & [245] \\
\hline & E. coli & $\begin{array}{l}\text { Flow cell system with } \\
\text { diamond-like carbon coating } \\
\text { modified by silicon (SICAN) } \\
\text { and SS coupons }\end{array}$ & $1-5 d$ & $\begin{array}{l}300 \mathrm{~L} / \mathrm{h} \\
(0.25 \mathrm{~Pa})\end{array}$ & $\begin{array}{l}\text { Effects of SICAN surfaces on } \\
\text { biofilm prevention and control }\end{array}$ & {$[246]$} \\
\hline & $\begin{array}{l}\text { L. monocytogenes spp. } \\
\text { From fish and meat production } \\
\text { plants }\end{array}$ & SS coupons & $24-240 \mathrm{~h}$ & $100 \mathrm{rpm}$ & $\begin{array}{l}\text { Biofilm formation for } \\
\text { understanding real } \\
\text { L. monocytogenes-carrying } \\
\text { consortia }\end{array}$ & {$[247]$} \\
\hline & E. coli & $\begin{array}{l}\text { Glass, SS and copper } \\
\text { coupons }\end{array}$ & $6 \mathrm{~h}$ & $\begin{array}{l}\text { Static } \\
115 \mathrm{rpm}(\mathrm{Re}= \\
2400,0.27 \mathrm{~Pa})\end{array}$ & $\begin{array}{l}\text { Biofilm formation under } \\
\text { different material surfaces, } \\
\text { nutrient concentration and } \\
\text { shear stress }\end{array}$ & [199] \\
\hline & $\begin{array}{l}\text { S. aureus } \\
\text { E. coli }\end{array}$ & PP coupons & $240 \mathrm{~h}$ & $50 \mathrm{rpm}$ & $\begin{array}{l}\text { Biofilm control by essential oils } \\
\text { of citronella and lemon }\end{array}$ & [248] \\
\hline & $\begin{array}{l}\text { Lactococcus lactis } \\
\text { L. monocytogenes }\end{array}$ & $\begin{array}{l}\text { Three channel flow cells } \\
\text { (Stovall } ® \text { ) with glass } \\
\text { coupons }\end{array}$ & $72 \mathrm{~h}$ & $1.5 \mathrm{~mL} / \mathrm{h}$ & Dual-species biofilm formation & [249] \\
\hline & L. monocytogenes & SS coupons & $240 \mathrm{~h}$ & $50 \mathrm{rpm}$ & $\begin{array}{l}\text { Biofilm control by essential oils } \\
\text { from Cymbopogon sp. }\end{array}$ & {$[250]$} \\
\hline $\begin{array}{l}\text { Fresh-cut food processing } \\
\text { plant }\end{array}$ & P. fluorescens & Pilot scale & $48 \mathrm{~h}$ & $150 \mathrm{~L} /(\operatorname{Re}=3300)$ & $\begin{array}{l}\text { Influence of flow pattern in } \\
\text { biofilm formation }\end{array}$ & [193] \\
\hline \multirow[t]{2}{*}{ Fruit processing industry } & $\begin{array}{l}\text { Kluyveromyces marxians } C \text {. } \\
\text { kruseiZygosaccharomyces spp. } \\
\text { R. mucilaginosa }\end{array}$ & $\begin{array}{l}\text { Flow chamber system with } \\
\text { SS coupons }\end{array}$ & $16-24 \mathrm{~h}$ & $\begin{array}{l}\text { Static1 } \mathrm{mL} / \mathrm{s}(\mathrm{Re}= \\
50)\end{array}$ & Yeast biofilm formation & [251] \\
\hline & Alicyclobacillus sp. & Glass coupons & $24-72 \mathrm{~h}$ & $\begin{array}{l}\text { Static } \\
60 \mathrm{rpm}\end{array}$ & Biofilm formation & {$[252]$} \\
\hline \multirow[t]{2}{*}{$\begin{array}{l}\text { Meat and fish processing } \\
\text { plants }\end{array}$} & Salmonella spp. & $\begin{array}{l}\text { 96-well PS microtiter plates; } \\
\text { Polyurethane (PU) and PP } \\
\text { coupons }\end{array}$ & $96 \mathrm{~h}$ & $\begin{array}{l}\text { Static } \\
100 \mathrm{rpm}\end{array}$ & $\begin{array}{l}\text { Biofilm formation and its } \\
\text { control }\end{array}$ & [253] \\
\hline & From processL. monocytogenes & SS coupons & $7 \mathrm{~d}$ & In situ & $\begin{array}{l}\text { Biofilm formation under } \\
\text { different environmental } \\
\text { conditions }\end{array}$ & [254] \\
\hline \multirow[t]{2}{*}{ Dairy processing industry } & $\begin{array}{l}\text { Paenibacillus polymyxaFrom } \\
\text { pasteurized milk }\end{array}$ & $\begin{array}{l}\text { Peroxide-cured silicone } \\
\text { tubing }\end{array}$ & $4 \mathrm{~d}$ & $\begin{array}{l}\mathrm{Re}=1400-2100 \\
\text { (laminar) }\end{array}$ & $\begin{array}{l}\text { Detection of different } \\
\text { structured deposits/biofilms }\end{array}$ & [255] \\
\hline & $\begin{array}{l}\text { L. monocytogenes } \\
\text { E. coli } \\
\text { P. aeruginosa }\end{array}$ & $\begin{array}{l}\text { Semicontinuous bioreactor- } \\
\text { like apparatus with SS } \\
\text { coupons }\end{array}$ & $24 \mathrm{~h}$ & - & $\begin{array}{l}\text { Biofilm control by neutral } \\
\text { electrolysed water }\end{array}$ & {$[256]$} \\
\hline \multirow[t]{3}{*}{ Paper industry } & From white water & $\begin{array}{l}\text { SS coupons; Pilot scale with } \\
\text { SS coupons }\end{array}$ & $\begin{array}{l}24 \mathrm{~h} \\
5-11 \mathrm{~d}\end{array}$ & Static- & $\begin{array}{l}\text { Biofilm control by plant- } \\
\text { derived compounds }\end{array}$ & {$[257]$} \\
\hline & From process water & $\begin{array}{l}\text { Continuous-flow reactors } \\
\text { with PVC coupons; Pilot } \\
\text { circuit with high density PP } \\
\text { coupons }\end{array}$ & $\begin{array}{l}1-4 \mathrm{~d} \\
1-10 \mathrm{~d}\end{array}$ & $\begin{array}{l}\mathrm{L} / \mathrm{s} \\
(\operatorname{Re}>2000)\end{array}$ & $\begin{array}{l}\text { Biofilm prevention by } \\
\text { enzymatic treatment }\end{array}$ & [258] \\
\hline & Enterobacter cloacae & $\begin{array}{l}\text { Pilot system with PVC } \\
\text { coupons }\end{array}$ & $96 \mathrm{~h}-10 \mathrm{~d}$ & $\begin{array}{l}0.10 \mathrm{~L} / \mathrm{s} \\
\text { (turbulent) }\end{array}$ & & [259] \\
\hline
\end{tabular}


Table 5 (continued)

\begin{tabular}{|c|c|c|c|c|c|c|}
\hline Industrial system & Microorganisms & System & Time & $\begin{array}{l}\text { Hydrodynamic } \\
\text { conditions }\end{array}$ & Main goal & Reference \\
\hline & & & & & $\begin{array}{l}\text { Biofilm prevention by } \\
\text { enzymatic products and its } \\
\text { monitoring }\end{array}$ & \\
\hline \multirow[t]{9}{*}{ Cooling water system } & From feed water & In situ & $5 m$ & In situ & $\begin{array}{l}\text { Effects of feed water and } \\
\text { continuous chlorine exposure } \\
\text { on biofilm formation and } \\
\text { control }\end{array}$ & {$[260]$} \\
\hline & Legionella pneumophila & $\begin{array}{l}100 \text { L PP pilot system with } \\
\text { SS coupons }\end{array}$ & $6 m$ & $40 \mathrm{~L} / \mathrm{min}$ & $\begin{array}{l}\text { Biofilm control by chloramine } \\
\mathrm{T}\end{array}$ & [261] \\
\hline & $\begin{array}{l}\text { Free-living amoebae (FLA) and } \\
\text { bacteria from freshwater }\end{array}$ & $\begin{array}{l}\text { Rotating disk reactor with SS } \\
\text { coupons }\end{array}$ & $10 \mathrm{~d}$ & $31000-850001 / \mathrm{s}$ & $\begin{array}{l}\text { Evaluation of colonization of } \\
\text { 'soft deformable' FLA particles } \\
\text { onto freshwater biofilm }\end{array}$ & [196] \\
\hline & $\begin{array}{l}\text { From make-up water of a } \\
\text { cooling tower }\end{array}$ & $\begin{array}{l}\text { Batch and semi-continuous } \\
\text { reactors with glass coupons }\end{array}$ & $28 \mathrm{~d}$ & - & $\begin{array}{l}\text { Biofilm control by green bio- } \\
\text { dispersants }\end{array}$ & {$[262]$} \\
\hline & From seawater & Pilot plant & $60 \mathrm{~d}$ & $800 \mathrm{~L} / \mathrm{h}(1.98 \mathrm{~m} / \mathrm{s})$ & $\begin{array}{l}\text { Fouling control by different } \\
\text { treatments }\end{array}$ & {$[263]$} \\
\hline & $\begin{array}{l}\text { From treated secondary } \\
\text { industrial wastewater and } \\
\text { clarified chlorinated river } \\
\text { freshwater }\end{array}$ & $\begin{array}{l}\text { In situ with glass, SS and } \\
\text { carbon steel coupons }\end{array}$ & $7 \mathrm{~d}$ & In situ & $\begin{array}{l}\text { Biofilm monitoring on two } \\
\text { industrial scale cooling tower } \\
\text { systems emplowing }\end{array}$ & [264] \\
\hline & From industrial water & Reactor with SS coupons & - & $100 \mathrm{rpm}$ & $\begin{array}{l}\text { Effects of environmental } \\
\text { parameters in biofilm } \\
\text { formation }\end{array}$ & [265] \\
\hline & L. pneumophila & $\begin{array}{l}\text { Pilot system with } \\
\text { SNIPACKING cooling tower } \\
\text { fill material and standard PP } \\
\text { fill material }\end{array}$ & $1-4 \mathrm{~m}$ & - & Biofilm prevention & [266] \\
\hline & $\begin{array}{l}\text { Sulphate-reducing bacteria } \\
\text { (SRB) from petrochemical } \\
\text { industry }\end{array}$ & In situ & $3 \mathrm{~m}$ & In situ & $\begin{array}{l}\text { Evaluation of resistance of } \\
\text { carbon steel alloys to } \\
\text { microbially induced corrosion } \\
\text { by SRB }\end{array}$ & [267] \\
\hline \multirow[t]{10}{*}{ Industrial fermentation } & $\begin{array}{l}\text { Trichoderma reesei } \\
\text { Trichoderma harzianum }\end{array}$ & $\begin{array}{l}\text { Drip flow reactor with } \\
\text { Teflon, glass, Viton }{ }^{\mathrm{TM}} \\
\text { rubber, silicon rubber and SS } \\
\text { coupons }\end{array}$ & $46 \mathrm{~h}$ & $11 \mathrm{~mL} / \mathrm{h}$ (laminar) & $\begin{array}{l}\text { Effects of surface material on } \\
\text { biofilm formation and } \\
\text { hydrophobin production }\end{array}$ & {$[268]$} \\
\hline & Aspergillus ochraceus & PE coupons & $26-74 \mathrm{~h}$ & $50 \mathrm{rpm}$ & $\begin{array}{l}\text { Biofilm formation for tannase } \\
\text { production }\end{array}$ & [269] \\
\hline & P. putida & $\begin{array}{l}\text { Custom-made biofilm } \\
\text { chamber of polycarbonate } \\
\text { (PC) }\end{array}$ & $4 \mathrm{~d}$ & $\begin{array}{l}31-312 \mathrm{~mL} / \mathrm{min} \\
(\operatorname{Re}=100-1000)\end{array}$ & $\begin{array}{l}\text { Biofilm formation in an upscale } \\
\text { experimental framework }\end{array}$ & {$[270]$} \\
\hline & E. coli & $\begin{array}{l}\text { Microchannel reactor with } \\
\text { surface modified by silane } \\
\text { reagent }\end{array}$ & $62 \mathrm{~h}$ & $45 \mu \mathrm{L} / \mathrm{min}$ & Biofilm formation & {$[271]$} \\
\hline & Bacillus subtilis & $\begin{array}{l}\text { Sartorius Biostat B Plus twin } \\
\text { system bioreactors with } \\
\text { plastic composite support } \\
\text { tubes }\end{array}$ & $144 \mathrm{~h}$ & $100-200 \mathrm{rpm}$ & $\begin{array}{l}\text { Biofilm formation for vitamin } \mathrm{K} \\
\text { (menaquinone-7) production }\end{array}$ & [272] \\
\hline & Pichia pastoris & PU foam cubes & $60-114 h$ & $250 \mathrm{rpm}$ & Biofilm formation & {$[273]$} \\
\hline & $\begin{array}{l}\text { Saccharomyces cerevisiae } \\
\text { A. niger }\end{array}$ & $\begin{array}{l}\text { Bioreactor with plastic } \\
\text { composite support tubes }\end{array}$ & $72 \mathrm{~h}$ & $150 \mathrm{rpm}$ & $\begin{array}{l}\text { Biofilm formation for ethanol } \\
\text { production }\end{array}$ & [274] \\
\hline & P. putida & $\begin{array}{l}\text { Three-channel flow } \\
\text { chambers covered with glass } \\
\text { coupons }\end{array}$ & $1-7 \mathrm{~d}$ & $3 \mathrm{~mL} / \mathrm{h}$ (laminar) & $\begin{array}{l}\text { Biofilm formation for } \\
\text { rhamnolipids production }\end{array}$ & {$[275]$} \\
\hline & S. cerevisiae & $\begin{array}{l}\text { Bioreactor with plastic } \\
\text { composite support tubes }\end{array}$ & $48 \mathrm{~h}$ & $100-300 \mathrm{rpm}$ & $\begin{array}{l}\text { Biofilm formation for ethanol } \\
\text { production }\end{array}$ & [276] \\
\hline & Kluyveromyces lactis & $\begin{array}{l}\text { Bioreactor with plastic } \\
\text { composite support tubes }\end{array}$ & $72 \mathrm{~h}$ & $100 \mathrm{rpm}$ & $\begin{array}{l}\text { Biofilm formation for lysozyme } \\
\text { production }\end{array}$ & [277] \\
\hline \multirow{4}{*}{$\begin{array}{l}\text { Water and wastewater } \\
\text { process systems (e.g. } \\
\text { cooling tower, heat } \\
\text { exchanger (HE), } \\
\text { treatment plant) }\end{array}$} & $\begin{array}{l}\text { From diluted domestic } \\
\text { wastewater }\end{array}$ & $\begin{array}{l}\text { Propella }{ }^{\mathrm{TM}} \text { reactor with SS } \\
\text { and micro-electro- } \\
\text { mechanical systems (MEMS) } \\
\text { coupons }\end{array}$ & $6 \mathrm{w}$ & $\begin{array}{l}\mathrm{Re}=1000 \\
\text { (laminar) }\end{array}$ & $\begin{array}{l}\text { Biofilm detection using MEMS } \\
\text { sensor }\end{array}$ & {$[278]$} \\
\hline & In situ & In situ & - & - & $\begin{array}{l}\text { Biofilm quantification and its } \\
\text { control }\end{array}$ & [279] \\
\hline & From activated sludge & $\begin{array}{l}\text { Sequencing batch biofilm } \\
\text { reactors with fibre threads } \\
\text { attached to the cylinders } \\
\text { distributed on their surfaces }\end{array}$ & $1 \mathrm{w}$ & - & $\begin{array}{l}\text { Biofilm formation for nitrogen } \\
\text { and phosphorous removal }\end{array}$ & {$[280]$} \\
\hline & $\begin{array}{l}\text { From raw sewage and brewery } \\
\text { wastewater }\end{array}$ & $\begin{array}{l}\text { Laboratory scale sewer } \\
\text { reactors of Perspex }\end{array}$ & $4 \mathrm{~m}$ & $240 \mathrm{rpm}$ & $\begin{array}{l}\text { Biofilm formation for the } \\
\text { evaluation of impact of } \\
\text { brewery wastewater discharge } \\
\text { on sulphide and methane } \\
\text { production in a sewer }\end{array}$ & {$[281]$} \\
\hline $\begin{array}{l}\text { Industrial pipelines and } \\
\text { processing equipment }\end{array}$ & Desulfovibrio vulgaris & $\begin{array}{l}\text { Anaerobic CDC biofilm } \\
\text { reactors with glass coupons; }\end{array}$ & $24-168 \mathrm{~h}$ & $\begin{array}{l}80 \mathrm{rpm} \\
\text { Static }\end{array}$ & $\begin{array}{l}\text { Genetic requirements for } \\
\text { biofilm formation }\end{array}$ & {$[282]$} \\
\hline
\end{tabular}




\begin{tabular}{|c|c|c|c|c|c|c|}
\hline Industrial system & Microorganisms & System & Time & $\begin{array}{l}\text { Hydrodynamic } \\
\text { conditions }\end{array}$ & Main goal & Reference \\
\hline & & \multicolumn{5}{|l|}{$\begin{array}{l}\text { Anaerobic Balch tubes with } \\
\text { glass coupons }\end{array}$} \\
\hline & P. fluorescens & Glass coupons & $24 \mathrm{~h}$ & $75 \mathrm{rpm}$ & $\begin{array}{l}\text { Biofilm dispersion by enzyme- } \\
\text { functionalized nano-bead } \\
\text { system }\end{array}$ & [283] \\
\hline & E. coli & $\begin{array}{l}\text { Flow cell reactor with PVC } \\
\text { coupons }\end{array}$ & $8 \mathrm{~d}$ & $\mathrm{Re}=4350-6720$ & $\begin{array}{l}\text { Effects of shear stress and mass } \\
\text { transfer on biofilm formation }\end{array}$ & [11] \\
\hline & E. coli & $\begin{array}{l}\text { Flow cell reactor with PVC } \\
\text { coupons }\end{array}$ & $11 \mathrm{~d}$ & $\begin{array}{l}242-374 \mathrm{~L} / \mathrm{h} \\
(\operatorname{Re}=4350-6720)\end{array}$ & Biofilm formation & {$[284]$} \\
\hline & $\begin{array}{l}\text { From fresh water and fuel } \\
\text { (diesel/biodiesel } 97 / 3 \mathrm{v} / \mathrm{v} \text { ) }\end{array}$ & Cylinders of carbon steel & $15 \mathrm{~d}$ & $1 \mathrm{~L} / \mathrm{s}$ & $\begin{array}{l}\text { Biofilm formation and } \\
\text { corrosion assessment }\end{array}$ & [285] \\
\hline & C. krusei & $\begin{array}{l}\text { Rotating disk system with SS } \\
\text { coupons }\end{array}$ & $1-4 d$ & $0-91 \mathrm{~Pa}$ & $\begin{array}{l}\text { Effect of shear stress on biofilm } \\
\text { formation }\end{array}$ & [195] \\
\hline & E. coli & $\begin{array}{l}\text { Flow cell reactor with PVC } \\
\text { coupons }\end{array}$ & $12 \mathrm{~d}$ & $\begin{array}{l}414 \mathrm{~L} / \mathrm{h} \\
(\operatorname{Re}=6000)\end{array}$ & $\begin{array}{l}\text { Effects of nutrient conditions } \\
\text { and turbulent flow on biofilm } \\
\text { formation }\end{array}$ & [194] \\
\hline & $\begin{array}{l}\text { E. coli } \\
\text { P. aeruginosa } \\
\text { Flavobacterium breve } \\
\text { Aeromonas hydrophila }\end{array}$ & Pilot plant with PC coupons & $5-15 d$ & $120 \mathrm{~L} / \mathrm{h}$ & $\begin{array}{l}\text { Biofilm prevention by } \\
\text { ultrasound treatment }\end{array}$ & {$[286]$} \\
\hline Bottled water industry & $\begin{array}{l}\text { From processed and bottled } \\
\text { water }\end{array}$ & Glass carriers & $6 \mathrm{~d}$ & $135 \mathrm{rpm}$ & $\begin{array}{l}\text { Biofilm formation and } \\
\text { monitoring }\end{array}$ & {$[287]$} \\
\hline $\begin{array}{l}\text { Purified water } \\
\text { distribution system }\end{array}$ & From purified water & $\begin{array}{l}\text { Biofilm annular reactor with } \\
\text { SS coupons }\end{array}$ & $7-14 \mathrm{~d}$ & $40-200 \mathrm{rpm}$ & $\begin{array}{l}\text { Effects of hydrodynamic } \\
\text { conditions on biofilm } \\
\text { formation }\end{array}$ & [288] \\
\hline $\begin{array}{l}\text { Metalworking fluid } \\
\text { systems (e.g. }\end{array}$ & P. aeruginosa & $\begin{array}{l}\text { CDC Biofilm Reactor with SS } \\
\text { coupons }\end{array}$ & $24-48 h$ & $125 \mathrm{rpm}$ & $\begin{array}{l}\text { Biofilm control by quorum } \\
\text { sensing inhibitors }\end{array}$ & [289] \\
\hline $\begin{array}{l}\text { machining, griding, and } \\
\text { milling operations) }\end{array}$ & $\begin{array}{l}\text { From metal manufacturing } \\
\text { plants }\end{array}$ & 96-well PS microtiter plates & $96 \mathrm{~h}$ & $\begin{array}{l}41 / \mathrm{min} \text { - rocking } \\
\text { frequency }\end{array}$ & $\begin{array}{l}\text { Biofilm control by coolants } \\
\text { contained biocides }\end{array}$ & {$[290]$} \\
\hline $\begin{array}{l}\text { Photobioreactors for } \\
\text { microalgal biomass } \\
\text { production }\end{array}$ & Nannochloropsis gaditana & $\begin{array}{l}\text { Open pond RW } \\
\text { photobioreactor with PC, } \\
\text { PC-rugged, SilicOne }{ }^{\circledR} \text {, Ultra- } \\
\text { Ever Dry }{ }^{\circledR} \text { and Plexiclean } \\
\text { samples }{ }^{\circledR}\end{array}$ & $2 \mathrm{~m}$ & $35 \mathrm{~cm} / \mathrm{s}$ & $\begin{array}{l}\text { Biofilm prevention by modified } \\
\text { surfaces }\end{array}$ & [291] \\
\hline
\end{tabular}

stress (turbulent flow), microorganisms can adhere and form mechanically resilient biofouling. Chang et al. [13] observed that under high shear stress (2.30 Pa), Bacillus spp. changed its shape and increased the production of extracellular polymeric substances to ensure robust cell adhesion. Also, the viscoelastic properties of biofouling were adjusted to shear stress conditions, becoming cohesive and solid-like under turbulent conditions [203,204]. Thus, it is obvious that biofouling formed under high shear stress is more difficult to eradicate by mechanical and chemical processes, affecting surface cleaning and disinfection efficiency, as demonstrated for $P$. fluorescens and $B$. cereus biofilms by Simões et al. [22,205,206]. In fact, biofouling formed under high shear stress $(0.17 \mathrm{~Pa})$ was more compact and resistant to a mechanical treatment and a combination of chemical (oxidizing and non-oxidizing sanitisers) and mechanical treatments than the "fluffy" biofouling formed under low shear stress (0.02 Pa) [197]. Therefore, biofouling is a ubiquitous phenomenon regardless the hydrodynamic conditions found in industrial settings. The biofouling control strategies must guarantee a maximum limit of biodeposit that does not affect the process productivity and product safety.

Several industrial processes are typically optimized by high shear stresses, which are characterized by high heat transfer efficiency, turbulent fluid distribution and high mixing performance. However, the benefits in process optimization and fouling resistance by high shear stress must overcome the negative effects on pressure drop. Several singularities are applied in industrial units to increase the overall shear stress and fluid turbulence, such as surface roughness, baffles, swirling flow, among others. For example, in a plate HE fouling mitigation was observed by increasing the wall shear stress and maintaining the pressure drop through the optimization of the arrangement of connections and changing the arrangement and specification of plates (e.g. the number of plates and corrugations type) [8]. Kulju et al. [102] verified that flow modifiers in the header section of a shell-and-tube HE increased the overall shear stress, reducing the probability of sedimentation, and consequent fouling development. Additionally, the surface roughness involves high heat transfer but also allows fouling formation and removal resistance due to dead-end zones near the asperities [7]. For smooth biofilm surfaces at the fluid velocity of 0.1 and $0.3 \mathrm{~m} / \mathrm{s}$, the ratio of bacterial detachment was from 1.3 to 1.4 times higher than from a rough biofilm surface [207]. Thus, during a unit process design, critical areas for fouling development and failure of CIP procedures must be avoided. For that, the estimation of shear stress distribution by a validated computational code will allow the prediction of fouling regions $[8,106,208]$. Therefore, shear stress should be kept higher than the maximum value that fouling could take place, aiming fouling removal and overcoming the deposition [3]. However, equipment design to avoid dead-end zones is preferred to the increase in fluid velocity, due to costs and equipment limitations.

Another significant feature is related to the increased interest in using NFs as working fluid in HEs that promotes high heat transfer under low fluid flow. However, under laminar flow the sedimentation of nanoparticles may be favoured, increasing the probability of fouling to occur $[2,88]$. In addition to their high conductivity, NFs have been studied as antimicrobial agents. Functional nanoparticles are a promising technology to control biofouling, providing a strategy to transport antimicrobial agents inside the biofouling structure. Habimana et al. [209] applied functional nanoparticles (gold nanoparticles with proteinase-K) for biofouling control, achieving both biocidal and matrix disruption effects against Pseudomonas fluorescens biofilms. Zinc oxide (ZnO) NF demonstrated dual-functionality as an antimicrobial agent [210] and fluid additive in HEs [211]. Furthermore, Awasthi et al. [212] verified that ZnO NF can control Bacillus subtilis biofouling by reducing their mass and density after exposure to increasing doses. However, the potential of NFs on biofouling prevention and control in HEs remains unexplored. 


\section{Conclusions}

A comprehensive analysis on the role of hydrodynamic conditions in industrial settings, particularly in biofouling development is provided. The main conclusions and future research needs are summarized as follows:

- Hydrodynamics plays an important role in the process effectiveness heat and mass transfer efficiency, pressure drop and mixing degree.

- Hydrodynamic conditions influence the structure, morphology and distribution of biofouling. High shear stress involves high transport of particles and nutrients towards the surface as well as high transport of sanitiser.

- Turbulent flow is typical in industrial settings.

- Biofouling is promoted under low hydrodynamics, while high CIP efficacy is carried out for high shear stress, improving biofouling removal.

- Singularities in process units (e.g. passive devices, elbows, valves, baffles, etc.) induce turbulence and increase the overall shear stress, improving the process effectiveness. However, critical areas for biofouling and CIP procedures are created near these structures.

- The equipment design is preferred to increasing shear stress (high fluid velocity), in which critical areas should be avoided based on prior simulation with validated computational analysis.

- Future research should involve new techniques to improve hydrodynamic conditions in industrial settings at a minimum possible pressure drop and biofouling development. Moreover, the potential of NFs as fluid additives in HEs and as biofouling prevention agents should be assessed.

\section{Declaration of Competing Interest}

The authors declare that they have no known competing financial interests or personal relationships that could have appeared to influence the work reported in this paper.

\section{Acknowledgements}

This work was financially supported by: Base Funding - UIDB/ 00511/2020 of LEPABE and UIDB/00081/2020 of CIQUP funded by national funds through the FCT/MCTES (PIDDAC); Project Biocide_for_Biofilm - PTDC/BII-BTI/30219/2017 - POCI-01-0145-FEDER030219, ABFISH - PTDC/ASP-PES/28397/2017 - POCI-01-0145FEDER-028397 and ALGAVALOR - POCI-01-0247-FEDER-035234, funded by FEDER funds through COMPETE2020 - Programa Operacional Competitividade e Internacionalização (POCI) and by national funds (PIDDAC) through FCT/MCTES; Portuguese Foundation for Science and Technology (FCT) under the scope of the strategic funding of UIDB/ 04469/2020 unit and BioTecNorte operation (NORTE-01-0145-FEDER000004) funded by the European Regional Development Fund under the scope of Norte2020 - Programa Operacional Regional do Norte; FCT/ SFRH/BD/147276/2019 (Susana Fernandes) and SFRH/BSAB/150379/ 2019 (Manuel Simões).

\section{Appendix A. Supplementary data}

Supplementary data to this article can be found online at https://doi. org/10.1016/j.cej.2021.129348.

\section{References}

[1] F. Coletti, B.D. Crittenden, S. Macchietto, Basic science of the fouling process, in F. Coletti, G.F. Hewitt (Eds.), Crude oil fouling - Deposit characterization, measurements, and modeling, Elsevier Inc., USA, 2015, pp. 23-50.

[2] H.S. Majdi, H.A. Alabdly, B.O. Hasan, M.M. Hathal, Oil fouling in double-pipe heat exchanger under liquid-liquid dispersion and the influence of copper oxide nanofluid, Heat Transfer - Asian Res. 48 (2019) 1963-1981.
[3] O.P. Arsenyeva, B. Crittenden, M. Yang, P.O. Kapustenko, Accounting for the thermal resistance of cooling water fouling in plate heat exchangers, Appl. Therm. Eng. 61 (2013) 53-59.

[4] J. Petit, T. Six, A. Moreau, G. Ronse, G. Delaplace, $\beta$-lactoglobulin denaturation, aggregation, and fouling in a plate heat exchanger: Pilot-scale experiments and dimensional analysis, Chem. Eng. Sci. 101 (2013) 432-450.

[5] M. Simões, M.O. Pereira, M.J. Vieira, Effect of mechanical stress on biofilms challenged by different chemicals, Water Res. 39 (2005) 5142-5152.

[6] B.Y. Zhang, S. Xu, J.A. Villalobos-Santeli, J.-Y. Huang, Fouling characterization of camel milk with comparison to bovine milk, J. Food Eng. 285 (2020), 110085.

[7] W. Bogacz, M. Lemanowicz, M.H. Al-Rashed, D. Nakonieczny, T. Piotrowski, J. Wójcik, Impact of roughness, wettability and hydrodynamic conditions on the incrustation on stainless steel surfaces, Appl. Therm. Eng. 112 (2017) 352-361.

[8] O.V. Demirskiy, P.O. Kapustenko, O.P. Arsenyeva, O.I. Matsegora, Y.A. Pugach, Prediction of fouling tendency in PHE by data of on-site monitoring. Case study at sugar factory, Appl. Therm. Eng. 128 (2018) 1074-1081.

[9] F. Bozzoli, L. Cattani, S. Rainieri, Cross-helix corrugation: The optimal geometry for effective food thermal processing, Int. J. Heat Mass Transf. 147 (2020), 118874.

[10] G. Li, L. Tang, X. Zhang, J. Dong, A review of factors affecting the efficiency of clean-in-place procedures in closed processing systems, Energy 178 (2019) $57-71$.

[11] J.M.R. Moreira, M. Simões, L.F. Melo, F.J. Mergulhão, The combined effects of shear stress and mass transfer on the balance between biofilm and suspended cell dynamics, Desalination Water Treat 53 (2014) 3348-3354.

[12] P.E.D. Augusto, M. Cristianini, Using computational fluid dynamics (CFD) for evaluation of fluid flow through a gate valve, Int. J. Food Eng. 8 (2012) 21.

[13] J. Chang, X. He, X. Bai, C. Yuan, The impact of hydrodynamic shear force on adhesion morphology and biofilm conformation of Bacillus sp, Ocean Eng. 197 (2020), 106860.

[14] G. Hwang, M.I. Klein, H. Koo, Analysis of the mechanical stability and surface detachment of mature Streptococcus mutans biofilms by applying a range of external shear forces, Biofouling 30 (2014) 1079-1091.

[15] C. Cunault, C. Faille, A. Calabozo-Delgado, T. Benezech, Structure and resistance to mechanical stress and enzymatic cleaning of Pseudomonas fluorescens biofilms formed in fresh-cut ready to eat washing tanks, J. Food Eng. 262 (2019) 154-161.

[16] S.I. Faria, R. Teixeira-Santos, M.J. Romeu, J. Morais, V. Vasconcelos, F. J. Mergulhão, The relative importance of shear forces and surface hydrophobicity on biofilm formation by coccoid cyanobacteria, Polymers (Basel) 12 (2020) 653.

[17] M. Simões, M.O. Pereira, M.J. Vieira, The role of hydrodynamic stress on the phenotypic characteristics of single and binary biofilms of Pseudomonas fluorescens, Water Sci. Technol. 55 (2007) 437-445.

[18] M. Simões, M.O. Pereira, S. Sillankorva, J. Azeredo, M.J. Vieira, The effect of hydrodynamic conditions on the phenotype of Pseudomonas fluorescens biofilms, Biofouling 23 (2007) 249-258.

[19] M. Simões, L.C. Simões, M.J. Vieira, Physiology and behavior of Pseudomonas fluorescens single and dual strain biofilms under diverse hydrodynamics stresses, Int. J. Food Microbiol. 128 (2008) 309-316.

[20] M. Simões, L.C. Simões, M.O. Pereira, M.J. Vieira, Sodium dodecyl sulfate allows the persistence and recovery of biofilms of Pseudomonas fluorescens formed under different hydrodynamic conditions, Biofouling 24 (2008) 35-44.

[21] M. Simões, S. Cleto, M.O. Pereira, M.J. Vieira, Influence of biofilm composition on the resistance to detachment, Water Sci. Technol. 55 (2007) 473-480.

[22] M. Simões, L.C. Simões, I. Machado, M.O. Pereira, M.J. Vieira, Control of flowgenerated biofilms with surfactants, Food Bioprod. Proc. 84 (2006) 338-345.

[23] M. Simões, L.C. Simões, M.J. Vieira, Species association increases biofilm resistance to chemical and mechanical treatments, Water Res. 43 (2009) 229-237.

[24] M. Simões, M.O. Pereira, M.J. Vieira, Monitoring the effects of biocide treatment of Pseudomonas fluorescens biofilms formed under different flow regimes, Water Sci. Technol. 47 (2002) 217-223.

[25] Y.A. Cengel, J.M. Cimbala, Fluid Mechanics - Fundamentals and Applications, Fourth ed., McGraw-Hill Education, New York, USA, 2017.

[26] I.B. Gomes, M. Simões, L.C. Simões, An overview on the reactors to study drinking water biofilms, Water Res. 62 (2014) 63-87.

[27] A. Bridier, R. Briandet, V. Thomas, F. Dubois-Brissonnet, Resistance of bacterial biofilms to disinfectants: A review, Biofouling 27 (2011) 1017-1032.

28] T. Møretrø, S. Langsrud, E. Heir, Bacteria on meat abattoir process surfaces after sanitation: Characterisation of survival properties of Listeria monocytogenes and the commensal bacterial flora, Adv. Microbiol. 03 (2013) 255-264.

[29] N. Marouani-Gadri, G. Augier, B. Carpentier, Characterization of bacterial strains isolated from a beef-processing plant following cleaning and disinfection Influence of isolated strains on biofilm formation by Sakai and EDL $933 \mathrm{E}$. coli O157:H7, Int. J. Food Microbiol. 133 (2009) 62-67.

[30] K.R. Goode, K. Asteriadou, P.T. Robbins, P.J. Fryer, Fouling and cleaning studies in the food and beverage industry classified by cleaning type, Compr. Rev. Food Sci. Food Saf. 12 (2013) 121-143.

[31] T.R. Bott, Industrial Biofouling, Elsevier, Amsterdam, 2011.

[32] H. Polman, F. Verhaart, M. Bruijs, Impact of biofouling in intake pipes on the hydraulics and efficiency of pumping capacity, Desalination Water Treat. 51 (2013) 997-1003.

[33] R. Fitzhenry, D. Weiss, D. Cimini, S. Balter, C. Boyd, L. Alleyne, R. Stewart, N. McIntosh, A. Econome, Y. Lin, I. Rubinstein, T. Passaretti, A. Kidney, P. Lapierre, D. Kass, J.K. Varma, Legionnaires' Disease outbreaks and cooling Towers, New York City, New York, USA, Emerg. Infect Dis. 23 (2017) 1769-1776. 
[34] F. George, T. Shivaji, C.S. Pinto, L.A.O. Serra, J. Valente, M.J. Albuquerque, P.C. O. Vicêncio, A. San-Bento, P. Diegues, P.J. Nogueira, T. Marques, H. Rebelo, F. Costa, R. Rodrigues, A. Nunes, V. Borges, J.P. Gomes, D. Sampaio, P. Barreiro, S. Duarte, D. Carpinteiro, J. Mendonça, C. Silva, L. Vieira, M.J. Simões, P. Gonçalves, B. Nunes, C. Dias, J. Machado, F. Almeida, E.A. Goncalves, L. Carvalho, P. Viterbo, D. Jardim, N. Lacasta, F. Boavida, A. Perez, I. Santana, P. Matias, N. Banza, C. Rabacal, A large outbreak of Legionnaires' disease in an industrial town in Portugal, Rev. Port. Sau Pub. 34 (2016) 199-208.

[35] F. Di Pippo, L. Di Gregorio, R. Congestri, V. Tandoi, S. Rossetti, Biofilm growth and control in cooling water industrial systems, FEMS Microbiol. Ecol. 94 (2018) fiy044.

[36] Y. Liu, W. Zhang, T. Sileika, R. Warta, N.P. Cianciotto, A.I. Packman, Disinfection of bacterial biofilms in pilot-scale cooling tower systems, Biofouling 27 (2011) 393-402.

[37] S. Galie, C. Garcia-Gutierrez, E.M. Miguelez, C.J. Villar, F. Lombo, Biofilms in the food industry: health aspects and control methods, Front. Microbiol. 9 (2018) 898.

[38] ECDC, Salmonellosis - Annual epidemiological report for 2017, Stockholm: European Centre for Disease Prevention and Control, 2020.

[39] ECDC, Listeriosis - Annual epidemiological report for 2017, Stockholm: European Centre for Disease Prevention and Control, 2020.

[40] H.C. Flemming, M. Meier, T. Schild, Mini-review: microbial problems in paper production, Biofouling 29 (2013) 683-696.

[41] A. Zumsteg, S.K. Urwyler, J. Glaubitz, Characterizing bacterial communities in paper production - troublemakers revealed, Microbiology 6 (2017), e00487.

[42] K. Mattila, A. Weber, M.S. Salkinoja-Salonen, Structure and on-site formation of biofilms in paper machine water flow, J. Ind. Microbiol. Biotechnol. 28 (2002) 268-279.

[43] P. Bajpai, Pulp and Paper Industry: Microbiological Issues in Papermaking, Elsevier, USA, 2015.

[44] U. Simunic, P. Pipp, M. Dular, D. Stopar, The limitations of hydrodynamic removal of biofilms from the dead-ends in a model drinking water distribution system, Water Res. 178 (2020), 115838.

[45] M.W. Cowle, G. Webster, A.O. Babatunde, B.N. Bockelmann-Evans, A. J. Weightman, Impact of flow hydrodynamics and pipe material properties on biofilm development within drinking water systems, Environ. Technol. 41 (2019) 3732-3744.

[46] K. Fish, A.M. Osborn, J.B. Boxall, Biofilm structures (EPS and bacterial communities) in drinking water distribution systems are conditioned by hydraulics and influence discolouration, Sci. Total Environ. 593-594 (2017) $571-580$.

[47] L.C. Simões, M. Simões, Biofilms in drinking water: problems and solutions, RSC Adv. 3 (2013) 2520-2533.

[48] C.E. Barrett, B.J. Pape, K.M. Benedict, M.A. Foster, V.A. Roberts, K. Rotert, M. C. Mattioli, J.S. Yoder, Impact of public health interventions on drinking water associated outbreaks of hepatitis A - United States, 1971-2017, MMWR 68 (2019) 766-770.

[49] E. Shin, J.-S. Kim, K.-H. Oh, S.S. Oh, M. Kwon, S. Kim, J. Park, H.S. Kwak, G. T. Chung, C.J. Kim, J. Kim, A waterborne outbreak involving hepatitis A virus genotype IA at a residential facility in the Republic of Korea in 2015, J. Clin. Virol, 94 (2017) 63-66.

[50] K. Nygård, B. Schimmer, Ø. Søbstad, A. Walde, I. Tveit, N. Langeland, T. Hausken, P. Aavitsland, A large community outbreak of waterborne giardiasis - delayed detection in a non-endemic urban area, BMC Public Health 6 (2006) 141.

[51] T. Hörmann, D. Suzzi, J.G. Khinast, Mixing and dissolution processes of pharmaceutical bulk materials in stirred tanks: Experimental and numerical investigations, Ind. Eng. Chem. Res. 50 (2011) 12011-12025.

[52] A. Ibarz, P.E.D. Augusto, Principles of unit operations in food processing, in: A. de Sousa Sant'Ana (Ed.) Quantitative microbiology in food processing: Modeling the microbial ecology, John Wiley \& Sons, Ltd. 2016, pp. 68-83.

[53] B. Ntamba, V. Fester, Pressure losses and limiting Reynolds numbers for nonNewtonian fluids in short square-edged orifice plates, J. Fluids Eng. 134 (2012), 091204.

[54] G. Kalayci, E.M. Ozbayoglu, S.Z. Miska, M. Yu, N. Takach, A. Saasen, R. May, Transition criteria for laminar to turbulent flow for Yield Power Law (YPL) fluids based on stability analysis, ASME 2013 Fluids Engineering Division Summer Metting Nevada, USA (2013), 16188.

[55] S.L.D. Kfuri, E.J. Soares, R.L. Thompson, R.N. Siqueira, Friction coefficients for Bingham and power-law fluids in abrupt contractions and expansions, J. Fluids Eng. 139 (2017), 021203.

[56] M. Moreau, N. Di Miceli Raimondi, N. Le Sauze, M. Cabassud, C. Gourdon, Pressure drop and axial dispersion in industrial millistructured heat exchange reactors, Chem. Eng. Process - Process Intensification 95 (2015) 54-62.

[57] A. Ghanem, T. Lemenand, D. Della Valle, H. Peerhossaini, Transport phenomena in passively manipulated chaotic flows: Split-and-recombine reactors, Proceedings of the ASME 2013 Fluids Engineering Division Summer Metting Nevada, USA (2013), 16077.

[58] S. Anitha, T. Thomas, V. Parthiban, M. Pichumani, What dominates heat transfer performance of hybrid nanofluid in single pass shell and tube heat exchanger? Adv. Powder Technol. 30 (2019) 3107-3117.

[59] S. Wang, J. Xiao, J. Wang, G. Jian, J. Wen, Z. Zhang, Configuration optimization of shell-and-tube heat exchangers with helical baffles using multi-objective genetic algorithm based on fluid-structure interaction, Int. Commun. Heat Mass Transfer 85 (2017) 62-69.
[60] B.I. Master, K.S. Chunangad, A.J. Boxma, D. Kral, P. Stehlík, Most frequently used heat exchangers from pioneering research to worldwide applications, Heat Transf. Eng. 27 (2006) 4-11.

[61] R.P. Singh, D.R. Heldman, Heat Transfer in Food Processing, Introduction to Food Engineering, Elsevier Inc., USA, 2014, pp. 265-419.

[62] P.K. Tamkhade, P.S. Purandare, M.M. Lele, Thermal analysis and performance evaluation of triple concentric tube heat exchanger, Int. J. Eng. Adv. Technol. 8 (2019) 3898-3905.

[63] M.J. Vieira, L.F. Melo, Preventing biofouling in heat exchangers: an experimental assessment of the effects of water velocity and inorganic particles on deposit detachment, in: M. Giot, F. Mayinger, G.P. Celata (Eds.), 4th ExHFT, Edizioni ETS, Brussels, Belgium, 1997, pp. 2087-2091.

[64] M. Malekan, A. Khosravi, Investigation of convective heat transfer of ferrofluid using CFD simulation and adaptive neuro-fuzzy inference system optimized with particle swarm optimization algorithm, Powder Technol. 333 (2018) 364-376.

[65] Z.S. Costa, C.T. Meneses, B. Castro, F.S. Serpa, E. Franceschi, G.R. Borges, C. Dariva, G.R. Salazar-Banda, Influence of magnetic field on barium sulfate incrustation from aqueous solutions, Heliyon 5 (2019), e02032.

[66] T. Alam, M.-H. Kim, A comprehensive review on single phase heat transfer enhancement techniques in heat exchanger applications, Renew. Sustain. Energ. Rev. 81 (2018) 813-839.

[67] D.J. Kukulka, R. Smith, Development and evaluation of enhanced heat transfer tubes for transitional Reynolds number flow, Chem. Eng. Trans. 29 (2012) 1489-1494.

[68] D.J. Kukulka, R. Smith, Enhanced heat transfer surface development for exterior tube surfaces, AIDIC Conf. Ser. 11 (2013) 191-200.

[69] H.T. Wang, W.B. Lee, J. Chan, S. To, Numerical and experimental analysis of heat transfer in turbulent flow channels with two-dimensional ribs, Appl. Therm. Eng. 75 (2015) 623-634.

[70] R. Mohebbi, M. Izadi, A. Amiri Delouei, H. Sajjadi, Effect of MWCNT-Fe $\mathrm{O}_{4}$ /water hybrid nanofluid on the thermal performance of ribbed channel with apart sections of heating and cooling, J. Therm. Anal. Calorim. 135 (2018) 3029-3042.

[71] R.K. Ajeel, W.S.I.W. Salim, A CFD study on turbulent forced convection flow of $\mathrm{Al}_{2} \mathrm{O}_{3}$-water nanofluid in semi-circular corrugated channel, IOP Conf. Series: Mater. Sci. Eng. 243 (2017), 012020.

[72] S. Mohebbi, F. Veysi, An experimental investigation on the heat transfer and friction coefficients of a small plate heat exchanger with chevron angle, Heat Mass Transf. 56 (2020) 849-858.

[73] I.K. Adegun, T.S. Jolayemi, O.A. Olayemi, A.M. Adebisi, Numerical simulation of forced convective heat transfer in inclined elliptic ducts with multiple internal longitudinal fins, Alex Eng. J. 57 (2018) 2485-2496.

[74] Q.-W. Wang, G.-D. Chen, J. Xu, Y.-P. Ji, Second-law thermodynamic comparison and maximal velocity ratio design of shell-and-tube heat exchangers with continuous helical baffles, J. Heat Transfer 132 (2010), 101801.

[75] A.A.H. Mostafa, E.E. Khalil, G. El-Hariry, E.M. Saad, W.A.A. Maksoud, On the modelling of shell and tube heat exchanger characteristics, 2018 Joint Thermophysics and Heat Transfer Conference, American Institute of Aeronautics and Astronautics, Atlanta, Georgia (2018), 3906.

[76] A.H. Ghitheeth, M. Fawzi, M.W. Aljibory, Experimental study of heat transfer enhancement by inserting metal chain in heat exchanger tube, IOP Conf. Series: Mater. Sci. Eng. 671 (2020), 012026.

[77] B. Meganathan, R.V. Yuvanarajan, P.V. Saravanan, A. Yuvaraj, Experimental investigation of heat transfer using "Twisted aluminium tape", Int. J. Eng. Res. Appl. 5 (2015) 1-4.

[78] Z. Tian, A. Abdollahi, M. Shariati, A. Amindoust, H. Arasteh, A. Karimipour, M. Goodarzi, Q.-V. Bach, Turbulent flows in a spiral double-pipe heat exchanger, Int. J. Numer. Method H 30 (2019) 39-53.

[79] S.S. Pawar, V.K. Sunnapwar, Studies on convective heat transfer through helical coils, Heat Mass Transf. 49 (2013) 1741-1754.

[80] T. Zhou, Z. Sun, Z. Dong, S. Li, J. Zhou, Mass flow measurement of fluids by a helically coiled tube, Sens. Transducers 152 (2013) 152-157.

[81] M. Abdollahi-M, K. Motahari, A. Rezaei, Performance characteristics of low concentrations of $\mathrm{CuO}$ /water nanofluids flowing through horizontal tube for energy efficiency purposes; an experimental study and ANN modeling, J. Mol. Liq. 271 (2018) 342-352.

[82] M. Raja, R. Vijayan, R. Vivekananthan, M.A. Vadivelu, Numerical investigation on heat transfer of $\mathrm{Al} 2 \mathrm{O}$ /water nanofluid in a shell and tube heat exchanger, AMM, Trans Tech Publications, Ltd., 2014, pp. 3-6.

[83] F. Yuan, J. Lin, J. Yu, Numerical research on convective heat transfer and resistance characteristics of turbulent duct flow containing nanorod-based nanofluids, J. Nanotechnol. 2018 (2018) 4349572.

[84] A.A. Minea, R.S. Luciu, O. Manca, Influence of microtube heating geometry on behavior of an alumina nanofluid at low Reynolds numbers, Appl. Mech. Mater. 371 (2013) 596-600.

[85] B. Li, Y. Lin, L. Zhu, W. Zhang, Effects of non-Newtonian behaviour on the thermal performance of nanofluids in a horizontal channel with discrete regions of heating and cooling, Appl. Therm. Eng. 94 (2016) 404-412.

[86] A.M. Hussein, M.M. Noor, K. Kadirgama, D. Ramasamy, M.M. Rahman, Heat transfer enhancement using hybrid nanoparticles in ethylene glycol through a horizontal heated tube, Int. J. Automot. Mech. Eng. 14 (2017) 4183-4195.

[87] E. Alvarez-Regueiro, J.P. Vallejo, J. Fernandez-Seara, J. Fernandez, L. Lugo, Experimental convection heat transfer analysis of a nano-enhanced industrial coolant, Nanomaterials (Basel) 9 (2019) 267.

[88] C.C. Tang, S. Tiwari, M.W. Cox, Viscosity and friction factor of aluminum oxidewater nanofluid flow in circular tubes, J. Nanotechnol. Eng. Med. 4 (2013), 021004. 
[89] N.G. Ivanov, A.I. Kirillov, E.M. Smirnov, V.V. Ris, Numerical modelling of buoyancy-induced fluid flow and heat transfer in a staggered tube bank, in Proceedings of the ASME 2010 14th International Heat Transfer Conference, Washington DC, USA, 2010, 22640.

[90] O. Manca, S. Nardini, D. Ricci, S. Tamburrino, Numerical analysis of nanofluid forced convection in ducts with triangular cross sections, in Proceedings of the ASME 2011 International Mechanical Engineering Congress \& Exposition, Colorado, USA, 2011, 62700 .

[91] O. Manca, S. Nardini, D. Ricci, S. Tamburrino, A numerical analysis on nanofluid mixed convection in triangular cross-sectioned ducts heated by a uniform heat flux, Adv. Mech. Eng. 7 (2015) 1-14.

[92] F. Bozzoli, L. Cattani, A. Mocerino, S. Rainieri, Experimental estimation of the local heat-transfer coefficient in coiled tubes in turbulent flow regime, J. Phys. Conf. Ser. 745 (2016), 032034.

[93] H. Srivastava, A. Dalal, K.C. Sahu, G. Biswas, Temporal linear stability analysis of an entry flow in a channel with viscous heating, Int. J. Heat Mass Transf. 109 (2017) 922-929.

[94] A.A.A.A. Alrashed, O.A. Akbari, A. Heydari, D. Toghraie, M. Zarringhalam, G.A S. Shabani, A.R. Seifi, M. Goodarzi, The numerical modeling of water/FMWCNT nanofluid flow and heat transfer in a backward-facing contracting channel, Phys. B Condens. Matter 537 (2018) 176-183.

[95] M. Mehrabi, Application of FCM-ANFIS approach to model heat transfer and pressure drop of Titania-water nanofluids in the turbulent flow regime, 19th International Conference on Thermal, Mechanical and Multi-Physics Simulation and Experiments in Microelectronics and Microsystems, Toulouse, France, 2018 $1-5$.

[96] K.D. Arvanitis, D. Bouris, E. Papanicolaou, Laminar flow and heat transfer in Ubends: The effect of secondary flows in ducts with partial and full curvature, Int. J. Therm. Sci. 130 (2018) 70-93.

[97] M. Mohammadpoor, S. Sabbaghi, M.M. Zerafat, Z. Manafi, Investigating heat transfer properties of copper nanofluid in ethylene glycol synthesized through single and two-step routes, Int. J. Refrig. 99 (2019) 243-250.

[98] H.A. Mohammed, F. Fathinia, H.B. Vuthaluru, S. Liu, CFD based investigations on the effects of blockage shapes on transient mixed convective nanofluid flow over a backward facing step, Powder Technol. 346 (2019) 441-451.

[99] F.E. Rodriguez-Corredor, M. Bizhani, M. Ashrafuzzaman, E. Kuru, An experimental investigation of turbulent water flow in concentric annulus using particle image velocimetry technique, J. Fluids Eng. 136 (2014), 051203.

[100] J.P. Vallejo, U. Calviño, I. Freire, J. Fernández-Seara, L. Lugo, Convective heat transfer in pipe flow for glycolated water-based carbon nanofluids. A thorough analysis, J. Mol. Liq. 301 (2020), 112370.

[101] K. Asteriadou, A.P.M. Hasting, M.R. Bird, J. Melrose, Modeling heat exchanger performance for non-Newtonian fluids, J. Food Process Eng. 33 (2010) $1010-1035$.

[102] T. Kulju, M. Riihimäki, T.M. Pääkkönen, O. Vilhunen, K. Lipiäinen, E. Muurinen, R. Keiski, Flow modifiers for preventing sedimentation in heat exchangers, J. Fluids Eng. 133 (2011), 101203.

[103] R. Barzegarian, A. Aloueyan, T. Yousefi, Thermal performance augmentation using water based $\mathrm{Al}_{2} \mathrm{O}_{3}$-gamma nanofluid in a horizontal shell and tube heat exchanger under forced circulation, Int. Commun. Heat Mass Transfer 86 (2017) $52-59$.

[104] J.B.B. Rao, V.R. Raju, Numerical and heat transfer analysis of shell and tube heat exchanger with circular and elliptical tubes, Int. J. Mech. Mater. Eng. 11 (2016) 6.

[105] M. Taws, C.T. Nguyen, N. Galanis, I. Gherasim, Experimental investigation of nanofluid heat transfer in a plate heat exchanger, in Proceedings of the ASME 2012 Summer Heat Transfer Conference, Rio Grande, Puerto Rico, 2012, 58016

[106] I.A. Stogiannis, S.V. Paras, O.P. Arsenyeva, P.O. Kapustenko, CFD modelling of hydrodynamics and heat transfer in channels of a PHE, Chem. Eng. Trans. 35 (2013) 1285-1290.

[107] F. Shen, C.-L. Chen, Z.-M. Liu, Vortices evolution in confined laminar radial flow between parallel discs, Chem. Eng. Sci. 116 (2014) 834-842.

[108] O.P. Arsenyeva, L.L. Tovazhnyanskyy, P.O. Kapustenko, G.L. Khavin, A. Yuzbashyan, Shell-and-plate heat exchangers for efficient heat recovery under the industrial application, Chem. Eng. Trans. 45 (2015) 1231-1236.

[109] G. Zhang, X. Lu, X. Du, M. Zeng, Q. Wang, Parametric study on flow and heat transfer performance of multi-flow spiral-wound heat exchanger, Chem. Eng. Trans. 39 (2014) 319-324.

[110] D.B. Pitz, A.T. Franco, C.O.R. Negrão, Effect of the Reynolds number on viscoelastic fluid flows through axisymmetric sudden contraction, J. Braz. Soc. Mech. Sci. Eng. 39 (2017) 1709-1720.

[111] H. Zhang, T. Xu, X. Zhang, Y. Wang, Y. Wang, X. Liu, Study on local resistance of non-Newtonian power law fluid in elbow pipes, J. Therm. Sci. 25 (2016) 287-291.

[112] A.M. Bluestein, R. Venters, D. Bohl, B.T. Helenbrook, G. Ahmadi, Turbulent flow through a ducted elbow and plugged tee geometry: An experimental and numerical study, J. Fluids Eng. 141 (2019), 081101.

[113] V.K. Singh, T. John Tharakan, Numerical simulations for multi-hole orifice flow meter, Flow Meas. Instrum. 45 (2015) 375-383.

[114] X. Sun, H.S. Kim, S.D. Yang, C.K. Kim, J.Y. Yoon, Numerical investigation of the effect of surface roughness on the flow coefficient of an eccentric butterfly valve, J. Mech. Sci. Technol. 31 (2017) 2839-2848.

[115] M. Coroneo, G. Montante, A. Paglianti, Computational fluid dynamics modeling of corrugated static mixers for turbulent applications, Ind. Eng. Chem. Res. 51 (2012) 15986-15996.

[116] B. Manshoor, I. Zaman, M.Z. Ngali, A. Khalid, Simulation of laminar mixing in fractal perforated plate static mixers, Adv. Mat. Res. 845 (2013) 31-35.
[117] J.-Q. Liu, Z.-F. Luo, K. Liu, Y.-F. Zhang, H.-X. Peng, B.-L. Hu, H.-X. Ren, X. Y. Zhou, S.-D. Qiu, X.-F. He, P. Ye, H. Bastani, L.-P. Lou, Effect of flushing on the detachment of biofilms attached to the walls of metal pipes in water distribution systems, J. Zhejiang Univ.-Sci. A (Appl. Phys. Eng.) 18 (2017) 313-328.

[118] L. Zhao, J. Derksen, R. Gupta, Simulations of axial mixing of Liquids in a long horizontal pipe for industrial applications, Energy Fuels 24 (2010) 5844-5850.

[119] T.A. Hoang, M. Ang, A.L. Rohl, Effects of process parameters on gypsum scale formation in pipes, Chem. Eng. Technol. 34 (2011) 1003-1009.

[120] C.G. Georgantopoulou, N.S. Vasilikos, G.A. Georgantopoulos, Recirculating flows analysis and estimation inside channels, MATEC Web Conf. 172 (2018) 01001.

[121] M. Weickert, G. Teike, O. Schmidt, M. Sommerfeld, Investigation of the LES WALE turbulence model within the lattice Boltzmann framework, Compus. Math. Appl. 59 (2010) 2200-2214.

[122] C. Cotas, F. Garcia, P. Ferreira, P. Faia, D. Asendrych, M.G. Rasteiro, ChangHsieh-Chen low-Reynolds $k-\varepsilon$ turbulence model adaptation to study the flow of concentrated pulp suspensions in pipes, 11th WCCM, 5th ECCM, 6th ECFD, Barcelona, Spain, 2014, pp. 7313-7324.

[123] C. Cotas, D. Asendrych, M. Graça Rasteiro, Numerical simulation of turbulent pulp flow of concentrated suspensions: Influence of the non-Newtonian properties of the pulp, Particul. Sci. Technol. 34 (2015) 442-452.

[124] M.M. Campagna, G. Dinardo, L. Fabbiano, G. Vacca, Fluid flow measurements by means of vibration monitoring, Meas. Sci. Technol. 26 (2015), 115306.

[125] R.A. Chaudhury, M. Herrmann, D.H. Frakes, R.J. Adrian, Length and time for development of laminar flow in tubes following a step increase of volume flux, Exp. Fluids 56 (2015) 22.

[126] Y. Jin, N. Yang, Q. Tong, Z. Jin, X. Xu, Rotary magnetic field combined with pipe fluid technique for efficient extraction of pumpkin polysaccharides, Innov. Food Sci. Emerg. Technol. 35 (2016) 103-110.

[127] M. Maraschin, K.F.S.H. Ferrari, A.P.H. da Silva, E. Carissimi, Aluminum sludge thickening: Novel helical pipes for aggregation by dual flocculation and thickening by filtration applied to water treatment plants, Sep. Purif. Technol. 241 (2020), 116560.

[128] C.G. Georgantopoulou, Inclination angle effect and separation zones estimation for incompressible flows inside pipes using sub-grids refinement, WSEAS Trans. Fluid Mech. 12 (2017) 116-130.

[129] A. Bergant, J. Greforc, T. Wahl, K. Urbanowicz, Analysis of pulsating flow in a large-scale pipeline close to resonance conditions, 13th International Conference on Pressure SurgesBordeaux, France, 2018, pp. 423-437.

[130] H. Sanaa, S. Hassan, B. Bennasser, A numerical modeling of a profile velocity and shear stress in transient flow applied in industrial technology, Period Eng. Nat. Sci. 6 (2018) 323-330.

[131] M. Haussmann, A.C. Barreto, G.L. Kouyi, N. Rivière, H. Nirschl, M.J. Krause, Large-eddy simulation coupled with wall models for turbulent channel flows at high Reynolds numbers with a lattice Boltzmann method - Application to Coriolis mass flowmeter, Comput. Math. Appl. 78 (2019) 3285-3302.

[132] H. Zhang, X. Zhang, H. Sun, M. Chen, X. Lu, Y. Wang, X. Liu, Pressure of Newtonian fluid flow through curved pipes and elbows, J. Therm. Sci. 22 (2013) 372-376.

[133] C.G. Georgantopoulou, A.K.M. Khan, N.S. Vasilikos, G.A. Georgantopoulos, Newtonian flow modeling through $90^{\circ}$ pipes bends, ARPN J. Eng. Appl. Sci. 11 (2016) 10110-10116.

[134] F. Aloui, E. Berrich, D. Pierrat, Experimental and numerical investigations of a turbulent flow behavior in isolated and nonisolated conical diffusers, J. Fluids Eng. 133 (2011), 011201.

[135] S. Woziwodzki, Ł. Jędrzejczak, Effect of eccentricity on laminar mixing in vessel stirred by double turbine impellers, Chem. Eng. Res. Des. 89 (2011) 2268-2278.

[136] Y. Han, J.-J. Wang, X.-P. Gu, L.-F. Feng, Numerical simulation on micromixing of viscous fluids in a stirred-tank reactor, Chem. Eng. Sci. 74 (2012) 9-17.

[137] D. Gomez-Rios, S. Junne, P. Neubauer, S. Ochoa, R. Rios-Estepa, H. RamirezMalule, Characterization of the metabolic response of Streptomyces clavuligerus to shear stress in stirred tanks and single-use 2D rocking motion bioreactors for clavulanic acid production, Antibiotics (Basel) 8 (2019) 168.

[138] G. Montante, A. Paglianti, Fluid dynamics characterization of a stirred model biomethanation digester, Chem. Eng. Res. Des. 93 (2015) 38-47.

[139] C. Walther, S. Mayer, A. Trefilov, G. Sekot, R. Hahn, A. Jungbauer, A. Durauer, Prediction of inclusion body solubilization from shaken to stirred reactors, Biotechnol. Bioeng. 111 (2014) 84-94.

[140] V. Baudron, P. Gurikov, I. Smirnova, A continuous approach to the emulsion gelation method for the production of aerogel micro-particle, Colloids Surf. A Physicochem. Eng. Asp. 566 (2019) 58-69.

[141] U.K. Abdulrasaq, I. Ayranci, The effect of hydrodynamic parameters on the production of Pickering emulsions in a baffled stirred tank, AIChE J. 65 (2019) $1-12$.

[142] M. Jaszczur, A. Młynarczykowska, L. Demurtas, Effect of impeller design on power characteristics and Newtonian fluids mixing efficiency in a mechanically agitated vessel at low Reynolds numbers, Energies 13 (2020) 640.

[143] Y. Kamla, H. Ameur, A. Karas, M.I. Arab, Performance of new designed anchor impellers in stirred tanks, Chem. Zvesti 74 (2019) 779-785.

[144] G. Mazzanti, M. Li, A.G. Marangoni, S.H.J. Idziak, Effects of shear rate variation on the nanostructure of crystallizing triglycerides, Cryst. Growth Des. 11 (2011) $4544-4550$.

[145] M. Yousuf, P.J. Frawley, Quantitative link between secondary nucleation and mixing hydrodynamics in batch cooling crystallization: a new approach in process development, Org. Process. Res. Dev. 23 (2019) 2009-2019. 
[146] Z. Harsfalvi, C. Jordan, B. Haddadi, M. Harasek, Computational fluid dynamic analysis of cooling in a mixed vessel using a non-Newtonian medium, Chem. Eng. Trans. 61 (2017) 565-570.

[147] V.d.S. Rosa, M.E.S. Taqueda, J.L. de Paiva, M.S. de Moraes, D. de Moraes, Nusselt's correlations in agitated tanks using the spiral coil with Rushton turbine and PBT $45^{\circ}$ impeller. Comparison with tanks containing vertical tube baffles, Appl. Therm. Eng. 110 (2017) 1331-1342.

[148] H.L.M. Lelieveld, J. Holah, D. Gabric, Handbook of Hygiene Control in the Food Industry, Woodhead Publishing, UK, 2016.

[149] S. Raposo, M.E. Lima-Costa, Effects of the hydrodynamic environment and oxygen mass transfer on plant cell growth and milk-clotting protease production in a stirred-tank reactor, Eng. Life Sci. 12 (2012) 441-449.

[150] L. Li, B. Xu, CFD simulation of local and global mixing time in an agitated tank, Chin. J. Mech. Eng. 30 (2017) 118-126.

[151] İ. Deniz, E. Imamoglu, F. Vardar Sukan, Evaluation of scale-up parameters of bioethanol production from Escherichia coli KO11, Turkish, J. Biochem. 40 (2015) 74-80.

[152] C. Li, X. Teng, H. Peng, X. Yi, Y. Zhuang, S. Zhang, J. Xia, Novel scale-up strategy based on three-dimensional shear space for animal cell culture, Chem. Eng. Sci. 212 (2020), 115329.

[153] B.J. Kim, T. Zhao, L. Young, P. Zhou, M.L. Shuler, Batch, fed-batch, and microcarrier cultures with $\mathrm{CHO}$ cell lines in a pressure-cycle driven miniaturized bioreactor, Biotechnol. Bioeng. 109 (2012) 137-145.

[154] D. Bulnes-A, L.M. Carrillo-C, D. Araiz-H, A. Garcia-U, M. Granados-P, P B. Sanchez-A, G. Murugappan, M.M. Alvarez, A simple eccentric stirred tank minibioreactor: mixing characterization and mammalian cell culture experiments, Biotechnol. Bioeng. 110 (2013) 1106-1118.

[155] M.C. Oliver-S, E. Morales-1, E. Durán-P, C. Orozco-Á, S. García-S, Shear rate and microturbulence effects on the synthesis of proteases by Jacaratia mexicana cells cultured in a bubble column, airlift, and stirred tank bioreactors, Biotechnol. Bioprocess. Eng. 18 (2013) 808-818.

[156] M.-L. Collignon, A. Delafosse, M. Crine, D. Toye, Axial impeller selection for anchorage dependent animal cell culture in stirred bioreactors: Methodology based on the impeller comparison at just-suspended speed of rotation, Chem. Eng. Sci. 65 (2010) 5929-5941.

[157] X. Li, J. Zhang, Y.L. Tan, Z.H. Li, X.F. Yu, J.Y. Xia, J. Chu, Y.Q. Ge, Effects of flow field on the metabolic characteristics of Streptomyces lincolnensis in the industrial fermentation of lincomycin, J. Biosci. Bioeng. 115 (2013) 27-31.

[158] J. Ramírez-M, R. Guadarrama-P, V.E. Márquez-B, A direct calculation method of the Metzner-Otto constant by using computational fluid dynamics, Chem. Eng. Sci. 174 (2017) 347-353.

[159] C.-I. Koncsag, A.E. Sterpu, A. Barbulescu, L. Barbes, Modeling the mixing process of industrial and domestic wastewater sludge, Environ. Eng. Manag. J. 14 (2015 1241-1246.

[160] L. Rahmani, B. Mebarki, B. Allaoua, B. Draoui, Laminar flow characterization in a stirred tank with a gate impeller in case of a non-Newtonian fluid, Energy Procedia 36 (2013) 418-427.

[161] F. Scargiali, A. Busciglio, F. Grisafi, A. Tamburini, G. Micale, A. Brucato, Power consumption in uncovered unbaffled stirred tanks: Influence of the viscosity and flow regime, Ind. Eng. Chem. Res. 52 (2013) 14998-15005.

[162] P. Dančová, L. Rahmani, O. Seghier, B. Draoui, E. Benachour, M. Veselý, Study of blades inclination influence of gate impeller with a non-Newtonian fluid of Bingham, EPJ Web Conf. 02101 (2016).

[163] E. Imamoglu, F.V. Sukan, Scale-up and kinetic modeling for bioethanol production, Bioresour. Technol. 144 (2013) 311-320.

[164] V. Stobiac, P.A. Tanguy, F. Bertrand, Investigation of the accuracy of the extrapolation method for the lattice Boltzmann simulation of viscous fluid flow in a Maxblend impeller system, Comput. Chem. Eng. 60 (2014) 112-123.

[165] G.C. Cudmore, A.G.L. Holloway, A.G. Gerber, A model of impeller whirl for baffled mixing vessels, J. Fluids Struct. 54 (2015) 719-742.

[166] I.A. Escamilla-Ruíz, F.Z. Sierra-Espinosa, J.C. García, A. Valera-Medina, F. Carrillo, Experimental data and numerical predictions of a single-phase flow in a batch square stirred tank reactor with a rotating cylinder agitator, Heat Mass Transf. 53 (2017) 2933-2949.

[167] C. Sirasitthichoke, P.M. Armenante, Power dissipation and power number correlations for a retreat-blade impeller under different baffling conditions, Ind. Eng. Chem. Res. 56 (2017) 10123-10133.

[168] F.L. Yang, S.J. Zhou, G.C. Wang, Experimental study and detached eddy simulation of the macro-instability in an eccentric stirred tank, Appl. Mech. Mater. 66-68 (2011) 20-26.

[169] F. Gumery, F. Ein-Mozaffari, Y. Dahman, Macromixing hydrodynamic study in draft-tube airlift reactors using electrical resistance tomography, Bioprocess Biosyst. Eng. 34 (2011) 135-144.

[170] Y. Pechaud, C.E. Marcato-Romain, E. Girbal-Neuhauser, I. Queinnec, Y. Bessiere, E. Paul, Combining hydrodynamic and enzymatic treatments to improve multispecies thick biofilm removal, Chem. Eng. Sci. 80 (2012) 109-118.

[171] S. Khali, R. Nebbali, D.E. Ameziani, K. Bouhadef, Numerical investigation of nonNewtonian fluids in annular ducts with finite aspect ratio using lattice Boltzmann method, Phys. Rev. E Stat. Nonlin. Soft Matter Phys. 87 (2013).

[172] A. Ohsawa, A. Murata, K. Iwamoto, Through-flow effects on Nusselt number and torque coefficient in Taylor-Couette-Poiseuille flow investigated by large eddy simulation, J. Therm. Sci. Technol. 11 (2016) 16-00356.

[173] T. Saur, E. Morin, F. Habouzit, N. Bernet, R. Escudie, Impact of wall shear stress on initial bacterial adhesion in rotating annular reactor, PLoS One 12 (2017), e0172113.
[174] N. Cagney, S. Balabani, Taylor-Couette flow of shear-thinning fluids, Phys. Fluids 31 (2019), 053102.

[175] U. Naseem, M.B. Awan, B. Saeed, N. Abbas, S. Nawaz, M. Hussain, Experimental investigation of flow instabilities in a wide gap turbulent rotating Taylor-Couette flow, Case Stud. Therm. Eng. 14 (2019), 100449.

[176] J.K. Sun, Y.I. Sobolev, W. Zhang, Q. Zhuang, B.A. Grzybowski, Enhancing crystal growth using polyelectrolyte solutions and shear flow, Nature 579 (2020) 73-79.

[177] M. Kotti, I. Ksentini, L. Ben Mansour, Impact of hydrodynamic regime on the capacity of oxygen transfer in a stirred electroflotation column, Desalination Water Treat. 52 (2013) 1693-1698.

[178] P.M. Doran, Mixing, in: P.M. Doran (Ed.) Bioprocess engineering principles, Elsevier Inc., USA, 2013, pp. 255-332.

[179] T. Nikolaeva, R. den Adel, R. van der Sman, K.J.A. Martens, H. Van As, A. Voda, J. van Duynhoven, Manipulation of recrystallization and network formation of oil-dispersed micronized fat crystals, Langmuir 35 (2019) 2221-2229.

[180] H. Ashassi-Sorkhabi, E. Asghari, M. Mohammadi, Effects of solution hydrodynamics on corrosion inhibition of steel by citric acid in cooling water, J. Mater. Eng. Perform. 23 (2014) 2992-3000.

[181] Q. de Radiguès, G. Thunis, J. Proost, On the use of 3-D electrodes and pulsed voltage for the process intensification of alkaline water electrolysis, Int. J. Hydrog Energy 44 (2019) 29432-29440.

[182] T. Toyoda, S. Ozasa, T. Ohishi, Design of a flow reactor system for safe handling of phosgenation reactions: Scale-up study of T-shaped mixers for industrial chemical production, J. Chem. Eng. Japan 52 (2019) 773-777.

[183] A. García, R. Herrero-Martin, J.P. Solano, J. Pérez-García, The role of insert devices on enhancing heat transfer in a flat-plate solar water collector, Appl. Therm. Eng. 132 (2018) 479-489.

[184] F.A.S. da Silva, D.J. Dezan, A.V. Pantaleão, L.O. Salviano, Longitudinal vortex generator applied to heat transfer enhancement of a flat plate solar water heater, Appl. Therm. Eng. 158 (2019), 113790.

[185] R. Ram kumar, S.T. Jaya Suthahar, C. Sakthivel, V. Vijayan, R. Yokeshwaran, Performance analysis of solar water heater by using $\mathrm{TiO}_{2}$ nanofluids, Mater. Today - Proc. 21 (2020) 817-819.

[186] D.J. Hernández-Melchor, R.O. Cañizares-Villanueva, J.R. Terán-Toledo, P. A. López- Pérez, E. Cristiani-Urbina, Hydrodynamic and mass transfer characterization of flat-panel airlift photobioreactors for the cultivation of a photosynthetic microbial consortium, Biochem. Eng. J. 128 (2017) 141-148.

[187] J.-L. Ramírez-Duque, M.-A. Ramos-Lucumi, Hydrodynamic computational evaluation in solar tubular photobioreactors bends with different cross sections, CT\&F - Cienc. Tecn. Fut. 4 (2011) 59-72.

[188] X. Chu, G. Yang, S. Pandey, B. Weigand, Direct numerical simulation of convective heat transfer in porous media, Int. J. Heat Mass Transf. 133 (2019) 11-20.

[189] F. Huang, D. Wang, Z. Li, Z. Gao, J.J. Derksen, Mixing process of two miscible fluids in a lid-driven cavity, Chem. Eng. J. 362 (2019) 229-242.

[190] W. Nan, Y. Wang, H. Sun, Experimental investigation on the packed bed of rodlike particles, Adv. Powder Technol. 30 (2019) 2541-2547.

[191] P. Bremer, B. Seale, S. Flint, J. Palmer, Biofilms in Dairy Processing, in: P. M. Fratamico, B.A. Annous, N.W. Gunther (Eds.), Biofilms in the food and beverage industries, Woodhead Publishing Limited, UK, 2009, pp. 396-431.

[192] L.M. Melo, M.M. Pinheiro, Biofilms in Water Distribution and Industrial Systems Biofouling in Heat Exchangers, in: L.F. Melo, T.R. Bott, M. Fletcher, B. Capdeville (Eds.), Biofilms - science and technology, Springer-Science+Business Media Dordrecht, Portugal, 1992, pp. 499-509.

[193] C. Cunault, C. Faille, L. Bouvier, H. Föste, W. Augustin, S. Scholl, P. Debreyne, T. Benezech, A novel set-up and a CFD approach to study the biofilm dynamics as a function of local flow conditions encountered in fresh-cut food processing equipments, Food Bioprod. Process 93 (2015) 217-223.

[194] J.S. Teodósio, M. Simões, L.F. Melo, F.J. Mergulhão, Flow cell hydrodynamics and their effects on $E$. coli biofilm formation under different nutrient conditions and turbulent flow, Biofouling 27 (2011) 1-11.

[195] L.I. Brugnoni, M.A. Cubitto, J.E. Lozano, Role of shear stress on biofilm formation of Candida krusei in a rotating disk system, J. Food Eng. 102 (2011) 266-271.

[196] A. Perrin, P. Herbelin, F.P.A. Jorand, S. Skali-Lami, L. Mathieu, Design of a rotating disk reactor to assess the colonization of biofilms by free-living amoebae under high shear rates, Biofouling 34 (2018) 368-377.

[197] M. Lemos, F. Mergulhão, L. Melo, M. Simões, The effect of shear stress on the formation and removal of Bacillus cereus biofilms, Food Bioprod. Proc. 93 (2015) $242-248$.

[198] I.B. Gomes, M. Lemos, L. Mathieu, M. Simões, L.C. Simões, The action of chemical and mechanical stresses on single and dual species biofilm removal of drinking water bacteria, Sci. Total Environ. 631-632 (2018) 987-993.

[199] J.M.R. Moreira, L.C. Gomes, M. Simões, L.F. Melo, F.J. Mergulhão, The impact of material properties, nutrient load and shear stress on biofouling in food industries, Food Bioprod. Proc. 95 (2015) 228-236.

[200] L. Yuan, M. Burmølle, F.A. Sadiq, N. Wang, G. He, Interspecies variation in biofilm-forming capacity of psychrotrophic bacterial isolates from Chinese raw milk, Food Control 91 (2018) 47-57.

[201] P.A. Araújo, J. Malheiro, I. Machado, F. Mergulhão, L. Melo, M. Simões, Influence of flow velocity on the characteristics of Pseudomonas fluorescens biofilms, J. Environ. Eng. 142 (2016) 04016031.

[202] E. Tsagkari, W.T. Sloan, Turbulence accelerates the growth of drinking water biofilms, Bioprocess. Biosyst. Eng. 41 (2018) 757-770.

[203] M.C. Tarifa, D. Genovese, J.E. Lozano, L.I. Brugnoni, In situ microstructure and rheological behavior of yeast biofilms from the juice processing industries, Biofouling 34 (2018) 74-85. 
[204] J. Hou, D.H. Veeregowda, B. van de Belt-Gritter, H.J. Busscher, H.C. van der Mei, Extracellular polymeric matrix production and relaxation under fluid shear and mechanical pressure in Staphylococcus aureus biofilms, Appl. Environ. Microbiol. 84 (2018) e01516-17.

[205] M. Simões, M.O. Pereira, M.J. Vieira, Action of a cationic surfactant on the activity and removal of bacterial biofilms formed under different flow regimes, Water Res. 39 (2005) 478-486.

[206] M. Simões, M.O. Pereira, M.J. Vieira, Effect of different concentrations of orthophthalaldehyde on biofilms formed by Pseudomonas fluorescens under different flow conditions, Biofouling 19 (2003) 287-295.

[207] Y. Shen, G.L. Monroy, N. Derlon, D. Janjaroen, C. Huang, E. Morgenroth, S A. Boppart, N.J. Ashbolt, W.T. Liu, T.H. Nguyen, Role of biofilm roughness and hydrodynamic conditions in Legionella pneumophila adhesion to and detachment from simulated drinking water biofilms, Environ. Sci. Technol. 49 (2015) 4274-4282.

[208] E. Diaz-Bejarano, E. Behranvand, F. Coletti, M.R. Mozdianfard, S. Macchietto, Organic and inorganic fouling in heat exchangers - Industrial case study: Analysis of fouling state, Appl. Energy 206 (2017) 1250-1266.

[209] O. Habimana, M. Zanoni, S. Vitale, T. O’Neill, D. Scholz, B. Xu, E. Casey, One particle, two targets: A combined action of functionalised gold nanoparticles, against Pseudomonas fluorescens biofilms, J. Colloid Interface Sci. 526 (2018) 419-428.

[210] A. Sirelkhatim, S. Mahmud, A. Seeni, N.H.M. Kaus, L.C. Ann, S.K.M. Bakhori, H. Hasan, D. Mohamad, Review on Zinc Oxide nanoparticles: Antibacterial activity and toxicity mechanism, Nanomicro Lett. 7 (2015) 219-242.

[211] R.N. Radkar, B.A. Bhanvase, D.P. Barai, S.H. Sonawane, Intensified convective heat transfer using $\mathrm{ZnO}$ nanofluids in heat exchanger with helical coiled geometry at constant wall temperature, Mater. Sci. Energy Technol. 2 (2019) 161-170.

[212] A. Awasthi, P. Sharma, L. Jangir, G. Kamakshi, K.K. Awasthi, K. Awasthi Awasthi, Dose dependent enhanced antibacterial effects and reduced biofilm activity against Bacillus subtilis in presence of ZnO nanoparticles, Mater. Sci. Eng. C Mater Biol. Appl. 113 (2020), 111021.

[213] J.E. Krol, D.C. Hall Jr., S. Balashov, S. Pastor, J. Sibert, J. McCaffrey, S. Lang, R. L. Ehrlich, J. Earl, J.C. Mell, M. Xiao, G.D. Ehrlich, Genome rearrangements induce biofilm formation in Escherichia coli C - an old model organism with a new application in biofilm research, BMC Genomics 20 (2019) 767.

[214] D. Kleine, J. Chodorski, S. Mitra, C. Schlegel, K. Huttenlochner, C. Muller-Renno, J. Mukherjee, C. Ziegler, R. Ulber, Monitoring of biofilms grown on differentially structured metallic surfaces using confocal laser scanning microscopy, Eng. Life Sci. 19 (2019) 513-521.

[215] H. Shen, E.A. Lopez-Guerra, R. Zhu, T. Diba, Q. Zheng, S.D. Solares, J.M. Zara, D. Shuai, Y. Shen, Visible-light-responsive photocatalyst of graphitic carbon nitride for pathogenic biofilm control, ACS Appl. Mater. Interfaces 11 (2019) 373-384.

[216] I. Turetgen, C. Vatansever, The efficacy of nano silver sulfadiazine and nano benzalkonium chloride on heterotrophic biofilms, Microbiology 88 (2019) 94-99.

[217] F. De Cesare, E. Di Mattia, E. Zussman, A. Macagnano, A study on the dependence of bacteria adhesion on the polymer nanofibre diameter, Environ. Sci. Nano 6 (2019) 778-797.

[218] K.P.S. Yau, A.B. Murphy, L. Zhong, A. Mai-Prochnow, Cold plasma effect on the proteome of Pseudomonas aeruginosa - Role for bacterioferritin, PLoS One 13 (2018), e0206530.

[219] V. Anthonydhason, J. Gopal, S. Chun, M. Muthu, Nanocarbon effect of smoking biofilms for effective control, J. Clust. Sci. 29 (2018) 541-548.

[220] J. Budil, P. Matyska Lišková, A. Artemenko, E. Ukraintsev, I. Gordeev, J. Beranová, I. Konopásek, A. Kromka, Anti-adhesive properties of nanocrystalline diamond films against Escherichia coli bacterium: Influence of surface termination and cultivation medium, Diam. Relat. Mater. 83 (2018) 87-93.

[221] J.A. Lemire, L. Kalan, N. Gugala, A. Bradu, R.J. Turner, Silver oxynitrate - an efficacious compound for the prevention and eradication of dual-species biofilms Biofouling 33 (2017) 460-469.

[222] C. Liu, J. Yang, L. Liu, B. Li, H. Yuan, W. Liu, Sodium lactate negatively regulates Shewanella putrefaciens CN32 biofilm formation via a three-component regulatory system (LrbS-LrbA-LrbR), Appl. Environ. Microbiol. 83 (2017) e00712-17.

[223] T.S. Kim, S.Y. Ham, B.B. Park, Y. Byun, H.D. Park, Lauroyl arginate ethyl blocks the iron signals necessary for Pseudomonas aeruginosa biofilm development, Front. Microbiol. 8 (2017) 970.

[224] H.S. Kim, E. Cha, Y. Kim, Y.H. Jeon, B.H. Olson, Y. Byun, H.D. Park, Raffinose, a plant galactoside, inhibits Pseudomonas aeruginosa biofilm formation via binding to LecA and decreasing cellular cyclic diguanylate levels, Sci. Rep. 6 (2016) 25318.

[225] A. Gillett, D. Waugh, J. Lawrence, M. Swainson, R. Dixon, Laser surface modification for the prevention of biofouling by infection causing Escherichia coli, J. Laser Appl. 28 (2016), 022503.

[226] K. Golberg, N. Emuna, T.P. Vinod, D. van Moppes, R.S. Marks, S.M. Arad, A. Kushmaro, Novel anti-adhesive biomaterial patches: preventing biofilm with Metal Complex Films (MCF) derived from a microalgal polysaccharide, Adv. Mater. Interfaces 3 (2016) 1500486.

[227] Y.Y. Cheng, C. Wu, J.Y. Wu, H.L. Jia, M.Y. Wang, H.Y. Wang, S.M. Zou, R.R. Sun, R. Jia, Y.Z. Xiao, FlrA represses transcription of the biofilm-associated bpfA operon in Shewanella putrefaciens, Appl. Environ. Microbiol. 83 (2017) e02410-16.

[228] E. Kvasnickova, O. Matatkova, A. Cejkova, J. Masak, Evaluation of baicalein, chitosan and usnic acid effect on Candida parapsilosis and Candida krusei biofilm using a Cellavista device, J. Microbiol. Meth. 118 (2015) 106-112.
[229] M. Harmsen, M. Lappann, S. Knochel, S. Molin, Role of extracellular DNA during biofilm formation by Listeria monocytogenes, Appl. Environ. Microbiol. 76 (2010) $2271-2279$.

[230] S.C. Chew, B. Kundukad, T. Seviour, J.R. van der Maarel, L. Yang, S.A. Rice, P. Doyle, S. Kjelleberg, Dynamic remodeling of microbial biofilms by functionally distinct exopolysaccharides, mBio 5 (2014) e01536-14.

[231] J.M. Moreira, J.S. Teodósio, F.C. Silva, M. Simões, L.F. Melo, F.J. Mergulhão, Influence of flow rate variation on the development of Escherichia coli biofilms, Bioprocess. Biosyst. Eng. 36 (2013) 1787-1796.

[232] Z. Sanchez, A. Tani, N. Suzuki, R. Kariyama, H. Kumon, K. Kimbara, Assessment of change in biofilm architecture by nutrient concentration using a multichannel microdevice flow system, J. Biosci. Bioeng. 115 (2013) 326-331.

[233] K. Hamid, K. Faten, E.A. Soumya, I.K. Saad, M. Hasna, L. Hassan, H. Moktar, Bacillus cereus adhesion: Real time investigation of the effect on the chemistry of industrial stainless steel, Microbiology 82 (2013) 22-28.

[234] A.K. Epstein, T.S. Wong, R.A. Belisle, E.M. Boggs, J. Aizenberg, Liquid-infused structured surfaces with exceptional anti-biofouling performance, Proc. Natl. Acad. Sci. USA 109 (2012) 13182-13187.

[235] G. Applerot, J. Lellouche, N. Perkas, Y. Nitzan, A. Gedanken, E. Banin, ZnO nanoparticle-coated surfaces inhibit bacterial biofilm formation and increase antibiotic susceptibility, RSC Adv. 2 (2012) 2314-2321.

[236] J.S. Teodósio, M. Simões, M.A. Alves, L.F. Melo, F.J. Mergulhão, Setup and validation of flow cell systems for biofouling simulation in industrial settings, Sci. World J. 2012 (2012), 361496.

[237] J. Gattlen, M. Zinn, S. Guimond, E. Korner, C. Amberg, L. Mauclaire, Biofilm formation by the yeast Rhodotorula mucilaginosa: process, repeatability and cell attachment in a continuous biofilm reactor, Biofouling 27 (2011) 979-991.

[238] S.M.A. Shibli, F. Chacko, $\mathrm{CeO}_{2}-\mathrm{TiO}_{2}$ mixed oxide incorporated high performance hot dip zinc coating, Surf. Coat. Technol. 205 (2011) 2931-2937.

[239] K. Sambanthamoorthy, A.A. Gokhale, W. Lao, V. Parashar, M.B. Neiditch, M. F. Semmelhack, I. Lee, C.M. Waters, Identification of a novel benzimidazole that inhibits bacterial biofilm formation in a broad-spectrum manner, Antimicrob. Agents Chemother. 55 (2011) 4369-4378.

[240] H. Ma, J.D. Bryers, Non-invasive method to quantify local bacterial concentrations in a mixed culture biofilm, J. Ind. Microbiol. Biotechnol. 37 (2010) 1081-1089.

[241] O. Kroukamp, R.G. Dumitrache, G.M. Wolfaardt, Pronounced effect of the nature of the inoculum on biofilm development in flow systems, Appl. Environ. Microbiol. 76 (2010) 6025-6031.

[242] A. Kaur, V. Rishi, S.K. Soni, P. Rishi, A novel multi-enzyme preparation produced from Aspergillus niger using biodegradable waste: A possible option to combat heterogeneous biofilms, AMB Express 10 (2020) 36.

[243] A. Meireles, R. Fulgêncio, I. Machado, F. Mergulhão, L. Melo, M. Simões, Characterization of the heterotrophic bacteria from a minimally processed vegetables plant, LWT 85 (2017) 293-300.

[244] J.M.R. Moreira, R. Fulgêncio, F. Oliveira, I. Machado, I. Bialuch, L.F. Melo, M. Simões, F.J. Mergulhão, Evaluation of SICON $®$ surfaces for biofouling mitigation in critical process areas, Food Bioprod. Proc. 98 (2016) 173-180.

[245] J. Malheiro, P. Araújo, I. Machado, M. Lemos, F. Mergulhão, L. Melo, M. Simões, The effects of selected brominated and chlorinated chemicals on Pseudomonas fluorescens planktonic cells and flow-generated biofilms, J. Food Proc. Preserv. 40 (2016) 316-328.

[246] J.M.R. Moreira, R. Fulgêncio, P. Alves, I. Machado, I. Bialuch, L.F. Melo, M. Simões, F.J. Mergulhão, Evaluation of SICAN performance for biofouling mitigation in the food industry, Food Control 62 (2016) 201-207.

[247] P. Rodriguez-Lopez, P. Saa-Ibusquiza, M. Mosquera-Fernandez, M. Lopez-Cabo, Listeria monocytogenes-carrying consortia in food industry. Composition, subtyping and numerical characterisation of mono-species biofilm dynamics on stainless steel, Int. J. Food Microbiol. 206 (2015) 84-95.

[248] F.M. Millezi, M.O. Pereira, N.N. Batista, N. Camargos, I. Auad, M.D.G. Cardoso, R. H. Piccoli, Susceptibility of monospecies and dual-species biofilms of Staphylococcus aureus and Escherichia coli to essential oils, J. Food Saf. 32 (2012) 351-359.

[249] O. Habimana, L. Guillier, S. Kulakauskas, R. Briandet, Spatial competition with Lactococcus lactis in mixed-species continuous-flow biofilms inhibits Listeria monocytogenes growth, Biofouling 27 (2011) 1065-1072.

[250] M.M.M.d. Oliveira, D.F. Brugnera, M.d.G. Cardoso, E. Alves, R.H. Piccoli, Disinfectant action of Cymbopogon sp. essential oils in different phases of biofilm formation by Listeria monocytogenes on stainless steel surface, Food Control 21 (2010) 549-553.

[251] L.I. Brugnoni, M.A. Cubitto, J.E. Lozano, Biofilm formation under laminar flow conditions of yeast isolated from an apple juice processing plant, J. Food Process Eng. 34 (2011) 49-66.

[252] A. Tyfa, A. Kunicka-Styczynska, J. Zabielska, Evaluation of hydrophobicity and quantitative analysis of biofilm formation by Alicyclobacillus sp, Acta Biochim. Pol. 62 (2015) 785-790.

[253] R.E. Ziech, A.P. Perin, C. Lampugnani, M.J. Sereno, C. Viana, V.M. Soares, J. G. Pereira, J.P.D.A.N. Pinto, L.d.S. Bersot, Biofilm-producing ability and tolerance to industrial sanitizers in Salmonella spp. isolated from Brazilian poultry processing plants, LWT 68 (2016) 85-90.

[254] P. Rodríguez-López, J.J. Rodríguez-Herrera, M.L. Cabo, Tracking bacteriome variation over time in Listeria monocytogenes-positive foci in food industry, Int. J. Food Microbiol. 315 (2020), 108439.

[255] O. Fysun, T. Anzmann, P. Gschwind, J. Rauschnabel, R. Kohlus, H.-C. Langowski, Biofilm and dairy fouling detection in flexible tubing using low-field NMR, Eur. Food Res. Technol. 245 (2019) 2579-2590. 
[256] M. Moradi, H. Tajik, Biofilm removal potential of neutral electrolysed water on pathogen and spoilage bacteria in dairy model systems, J. Appl. Microbiol. 123 (2017) 1429-1437.

[257] C. Neyret, J.M. Herry, T. Meylheuc, F. Dubois-Brissonnet, Plant-derived compounds as natural antimicrobials to control paper mill biofilms, J. Ind. Microbiol. Biotechnol. 41 (2014) 87-96.

[258] C.E. Torres, G. Lenon, D. Craperi, R. Wilting, A. Blanco, Enzymatic treatment for preventing biofilm formation in the paper industry, Appl. Microbiol. Biotechnol. 92 (2011) 95-103.

[259] A. Blanco, E. Torres, E. Fuente, C. Negro, New tool to monitor biofilm growth in industrial process waters, Ind. Eng. Chem. Res. 50 (2011) 5766-5773.

[260] I.S.M. Pinel, D.H. Moed, J.S. Vrouwenvelder, M.C.M. van Loosdrecht, Bacterial community dynamics and disinfection impact in cooling water systems, Water Res. 172 (2020), 115505.

[261] N.O. Sanli, Evaluation of biocidal efficacy of Chloramine T trihydrate on planktonic and sessile bacteria in a model cooling tower water system, Water Sci. Technol. 79 (2019) 526-536.

[262] F. Di Pippo, F. de Tora, L. Di Gregorio, M. Buccolini, R. Capocecera, S. Rossetti, V. Tandoi, Green bio-dispersant removal efficacy estimation for controlling biofilms in cooling towers, Ann. Microbiol. 67 (2017) 779-784.

[263] D. Rubio, J.F. Casanueva, E. Nebot, Assessment of the antifouling effect of five different treatment strategies on a seawater cooling system, Appl. Therm. Eng. 85 (2015) 124-134.

[264] V.L. Dos Santos, A.A. Veiga, R.S. Mendonca, A.L. Alves, S. Pagnin, V.M. Santiago, Reuse of refinery's tertiary-treated wastewater in cooling towers: Microbiological monitoring, Environ. Sci. Pollut. Res. Int. 22 (2015) 2945-2955.

[265] F. Liu, W. Dong, F. Yang, L. Lu, Y. Wang, X. Yin, C. Zhao, Effect of $\mathrm{CaCO}_{3}$ particles and suspended bacteria on biofilm components and activity in the model recirculating cooling water system, World J. Microbiol. Biotechnol. 28 (2012) $881-889$.

[266] I. Turetgen, N.O. Sanli, I. Norden, Biofilm formation comparison of the SANIPACKING ${ }^{\circledR}$ cooling tower fill material against standard polypropylene fill material in a recirculating model water system Turk, J. Biol. 36 (2012) 313-318.

[267] A. Prithiraj, I.O. Otunniyi, P. Osifo, J. van der Merwe, Corrosion behaviour of stainless and carbon steels exposed to sulphate - reducing bacteria from industrial heat exchangers, Eng. Fail Anal. 104 (2019) 977-986.

[268] F. Bajoul Kakahi, S. Ly, C. Tarayre, O. Deschaume, C. Bartic, P. Wagner, P. Compere, G. Derdelinckx, C. Blecker, F. Delvigne, Modulation of fungal biofilm physiology and secondary product formation based on physico-chemical surface properties, Bioprocess. Biosyst. Eng. 42 (2019) 1935-1946.

[269] F.M. Aracri, R.M.F. Cavalcanti, L.H.S. Guimarães, Extracellular tannase from Aspergillus ochraceus: influence of the culture conditions on biofilm formation, enzyme production, and application, J. Microbiol. Biotechnol. 29 (2019) 1749-1759.

[270] D.R. Espeso, E. Martínez-García, A. Carpio, V. de Lorenzo, Dynamics of Pseudomonas putida biofilms in an upscale experimental framework, J. Ind. Microbiol. Biotechnol. 45 (2018) 899-911.

[271] C.-T. Zhu, Y.-Y. Mei, L.-L. Zhu, Y. Xu, S. Sheng, J. Wang, Recombinant Escherichid coli BL21-pET28a-egfp cultivated with nanomaterials in a modified microchannel for biofilm formation, Int. J. Mol. Sci. 19 (2018) 2590.

[272] E. Mahdinia, A. Demirci, A. Berenjian, Optimization of Bacillus subtilis natto growth parameters in glycerol-based medium for vitamin K (Menaquinone-7) production in biofilm reactors, Bioprocess. Biosyst. Eng. 41 (2018) 195-204.

[273] J. Lima-Pérez, D. Rodríguez-Gómez, O. Loera, G. Viniegra-González, M. LópezPérez, Differences in growth physiology and aggregation of Pichia pastoris cells between solid-state and submerged fermentations under aerobic conditions, J. Chem. Technol. Biotechnol. 93 (2018) 527-532.
[274] G. Izmirlioglu, A. Demirci, Simultaneous saccharification and fermentation of ethanol from potato waste by co-cultures of Aspergillus niger and Saccharomyces cerevisiae in biofilm reactors, Fuel 202 (2017) 260-270.

[275] V. Wigneswaran, K.F. Nielsen, C. Sternberg, P.R. Jensen, A. Folkesson, L. Jelsbak, Biofilm as a production platform for heterologous production of rhamnolipids by the non-pathogenic strain Pseudomonas putida KT2440, Microb. Cell Fact. 15 (2016) 181.

[276] G. Izmirlioglu, A. Demirci, Ethanol production in biofilm reactors from potato waste hydrolysate and optimization of growth parameters for Saccharomyces cerevisiae, Fuel 181 (2016) 643-651.

[277] D. Ercan, A. Demirci, Production of human lysozyme in biofilm reactor and optimization of growth parameters of Kluyveromyces lactis K7, Appl. Microbiol. Biotechnol. 97 (2013) 6211-6221.

[278] Y. Boukazia, G. Delaplace, M. Cadé, F. Bellouard, L. Fillaudeau, On-line biofouling monitoring and qualification based on local thermal and periodic excitation with MEMS sensor, Food Bioprod. Proc. 126 (2021) 12-22.

[279] T.S. Rao, R. Kumar, P. Balamurugan, G.K. Vithal, Microbial fouling in a water treatment plant and its control using biocides, Biocontrol Sci. 22 (2017) 105-119.

[280] Y. Jin, D. Ding, C. Feng, S. Tong, T. Suemura, F. Zhang, Performance of sequencing batch biofilm reactors with different control systems in treating synthetic municipal wastewater, Bioresour. Technol. 104 (2012) 12-18.

[281] G. Sudarjanto, K.R. Sharma, O. Gutierrez, Z. Yuan, A laboratory assessment of the impact of brewery wastewater discharge on sulfide and methane production in a sewer, Water Sci. Technol. 64 (2011) 1614-1619.

[282] K.B. De León, G.M. Zane, V.V. Trotter, G.P. Krantz, A.P. Arkin, G.P. Butland, P.J. Walian, M.W. Fields, J.D. Wall, Unintended laboratory-driven evolution reveals genetic requirements for biofilm formation by Desulfovibrio vulgaris Hildenborough, mBio 8 (2017), e01696-17.

[283] M. Zanoni, O. Habimana, J. Amadio, E. Casey, Antifouling activity of enzymefunctionalized silica nanobeads, Biotechnol. Bioeng. 113 (2016) 501-512.

[284] J.S. Teodósio, F.C. Silva, J.M. Moreira, M. Simões, L.F. Melo, M.A. Alves, F. J. Mergulhão, Flow cells as quasi-ideal systems for biofouling simulation of industrial piping systems, Biofouling 29 (2013) 953-966.

[285] I.R. Melo, S.L.U. Filho, F.J.S. Oliveira, F.P. de França, Formation of biofilms and biocorrosion on AISI-1020 carbon steel exposed to aqueous systems containing different concentrations of a diesel/biodiesel mixture, Int. J. Corros. 2011 (2011), 415920.

[286] N. Lambert, H. Rediers, A. Hulsmans, K. Joris, P. Declerck, Y. De Laedt, S. Liers, Evaluation of ultrasound technology for the disinfection of process water and the prevention of biofilm formation in a pilot plant, Water Sci. Technol. 61 (2010) 1089-1096.

[287] A. Rygala, J. Berlowska, D. Kregiel, Heterotrophic plate count for bottled water safety management, Processes 8 (2020) 739.

[288] M. Florjanic, J. Kristl, The control of biofilm formation by hydrodynamics of purified water in industrial distribution system, Int. J. Pharm. 405 (2011) 16-22.

[289] S.S. Ozcan, M. Dieser, A.E. Parker, N. Balasubramanian, C.M. Foreman, Quorum sensing inhibition as a promising method to control biofilm growth in metalworking fluids, J. Ind. Microbiol. Biotechnol. 46 (2019) 1103-1111.

[290] E.A. Trafny, R. Lewandowski, K. Kozłowska, I. Zawistowska-Marciniak, M. Stępińska, Microbial contamination and biofilms on machines of metal industry using metalworking fluids with or without biocides, Int. Biodeterior. Biodegr. 99 (2015) 31-38.

[291] O. Zeriouh, A. Marco-Rocamora, J.V. Reinoso-Moreno, L. Lopez-Rosales, F. Garcia-Camacho, E. Molina-Grima, New insights into developing antibiofouling surfaces for industrial photobioreactors, Biotechnol. Bioeng. 116 (2019) $2212-2222$. 